D3L L J. S. DEPARTMENT OF AGRICULTURE BIOLOGICAL SURV.PY-BULLETIN No. 36

HENRY W. HENSHAW, Chief

\title{
RAISING DEER AND OTHER LARGE GAME ANIMALS IN THE UNITED STATES
}

$\mathrm{BY}$

DAVID E. LANTZ

Assistant, Biological Suriey

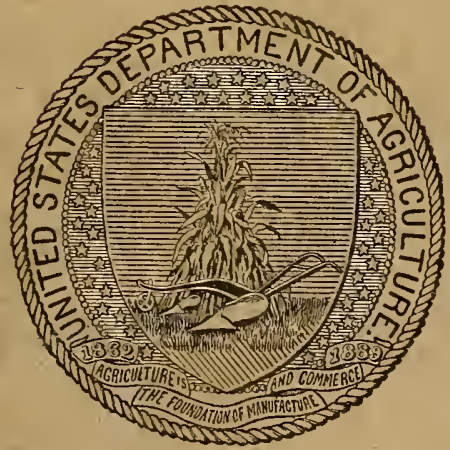

WASHINGTON

GOVERNMENT PRINTING OFFICE 


$$
\text { ช }
$$



. 



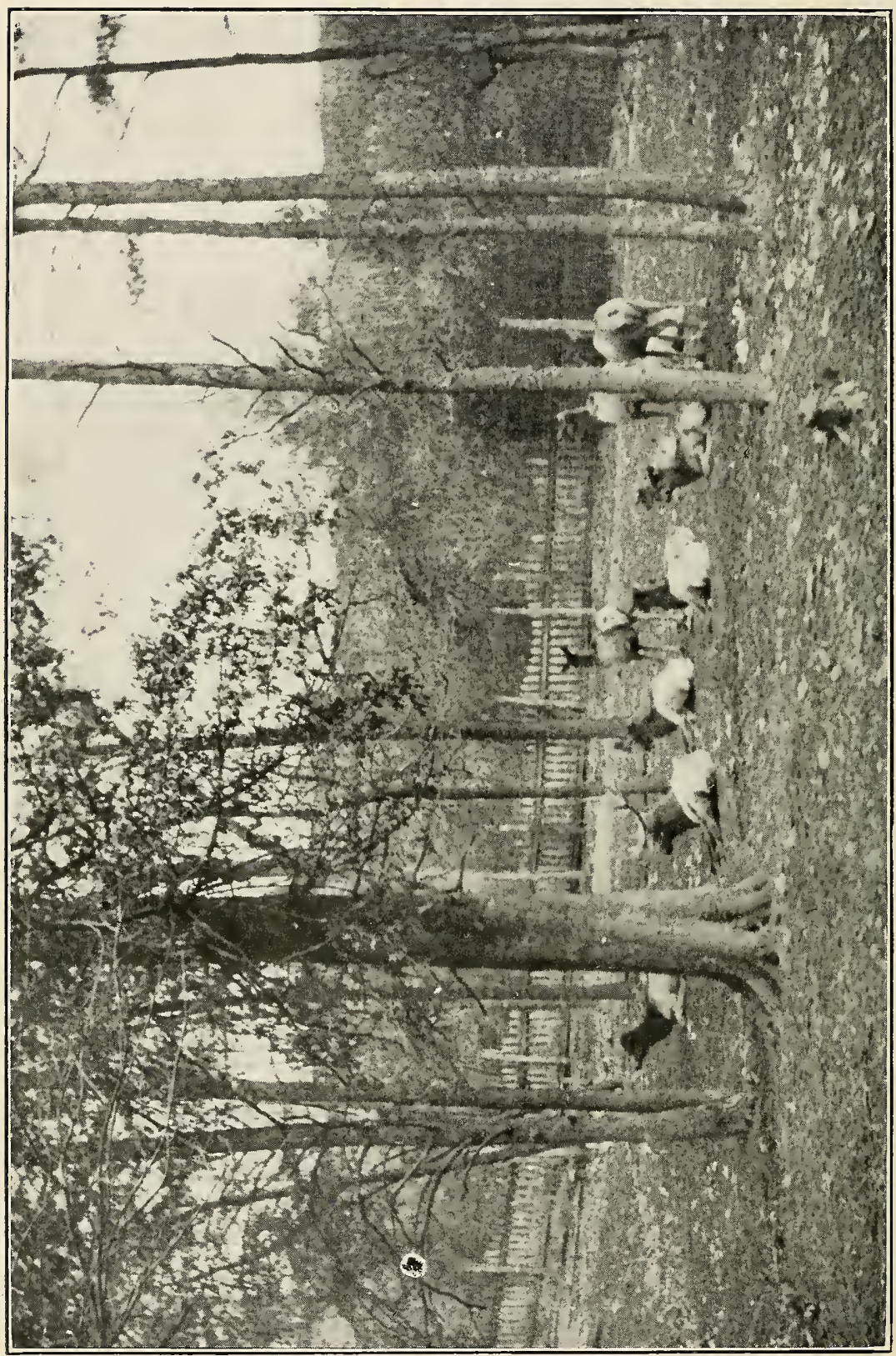


U. S. DEPARTIENT OF AGRICULTURE BIOLOGICAL SURVEY-BULLETIN No. 36

HENRY W. HENSHAW, Chief

\section{RAISING DEER AND OTHER LARGE GAIIE}

\section{ANIMALS IN THE UNITED STATES}

BY

DAVID E. LANTZ

Assistant, Biological Survey

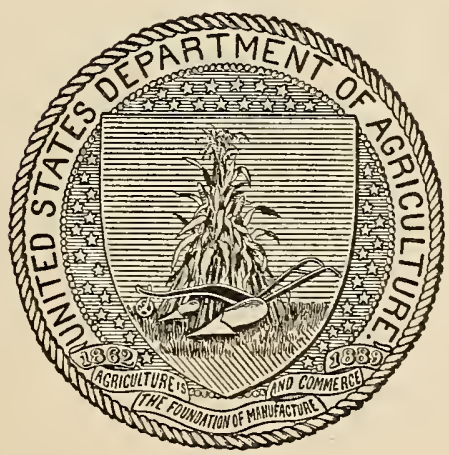

WASHINGTON

GOVERNMENT PRINTING OFFICE 1910

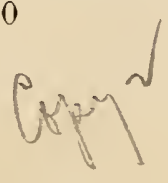




$$
S^{3 x^{0}} \hat{H}^{b^{2}}
$$




\section{LETTER OF TRANSWITTAL.}

\section{U. S. Departuent of Agriculture,}

Biological SuRvex,

Washington, D. C., Oct. 4, 1910.

SIR: I have the honor to transmit herewith, as Bulletin No. 36 of the Biological Survey, the results of an investigation by David E. Lantz concerning the practicability and desirability of raising deer and other large game animals in the United States.

In most parts of the country the number of game animals is steadily diminishing and game for table use has already become a high-priced luxury. Experiments have shown that some species, especially of the deer family, can be brought to a state of semidomestication with comparative ease and can be bred and raised at very small cost. The chief purpose of the present bulletin is to call attention to the importance of raising elk and deer for venison, to indicate the particular species most readily reared in preserves, and to emphasize the importance of so modifying state game laws as to encourage the use of private effort and capital in making a marketable commodity of venison and placing it within the reach of people of moderate means. Since the distribution in 1908 of our earlier publication on Deer Farming (Farmers' Bulletin 330) several States have changed their game laws in the interest of this industry, and as its importance becomes known others are sure to follow.

Attention is again directed to the fact that in many parts of the country there are tracts of land of little or no value for agricultural purposes which can be more profitably used for raising venison than for any other purpose.

Respectfully,

Hon. Janes WiLson, Secretary of Agriculture.
Henry IV. Henshaw, Chief, Biological Survey. 



\section{CONTENTS.}

Introduction ......................... Page.

Importance of domesticating mammals............................ 8

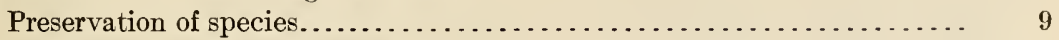

Use in agriculture and transportation......................... 10

Use for fur........................................... 10

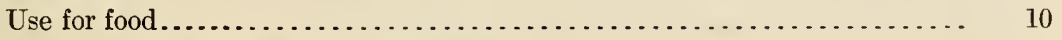

Selection of species for rearing experiments...................... 10

The pronghorn, or American antelope........................ 11

Exotic antelopes.............................................. 13

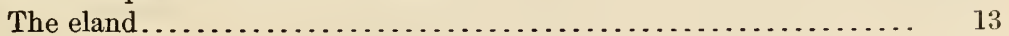

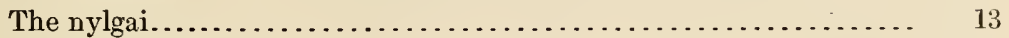

Smaller antelopes......................................... 14

Importance of the deer family.............................. 14

Native deer of North America............................... 16

Caribou.................................................. 16

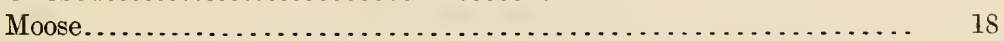

Wapiti, or round-horned elk.............................. 19

White-tailed deer....................................... 20

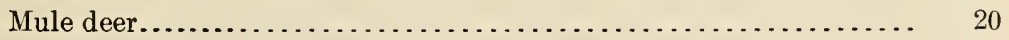

Columbia black-tailed deer............................ 21

Exotic deer................................................. 21

Altai wapiti.................................................. 21

Japanese sika............................................ 22

The Père David deer .................................. 23

Indian sambar............................................ 23

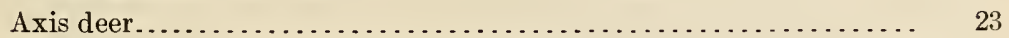

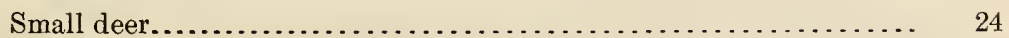

Objections to the introduction of foreign animals................. 24

The wapiti, or Rocky Mountain elk ............................ 25

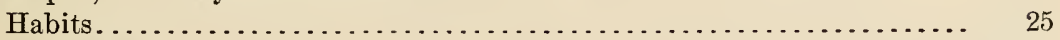

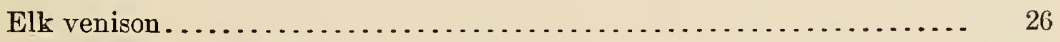

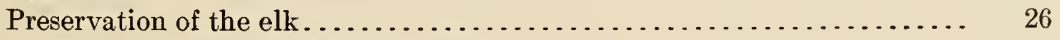

Wild elk in the eastern United States......................... 27

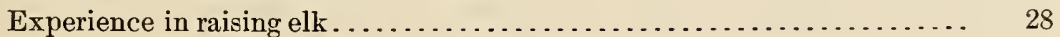

Elk in the Ozark Mountains.................................. 33

Management of elk in inclosures............................ 36

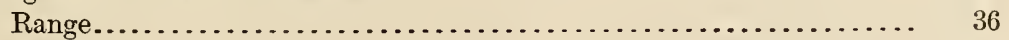

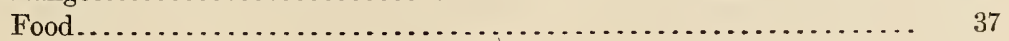

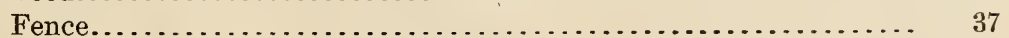

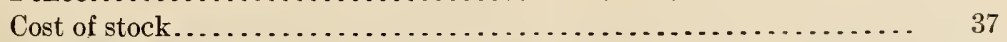

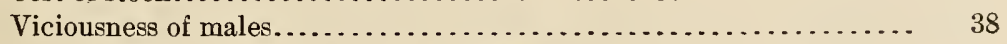

The elk as an enemy of wolves and dogs................... 39 
Page.

The whitetail, or Virginia deer............................. ${ }_{40}^{4}$

Experiences of breeders.................................. 42

A domesticated herd of deer............................. 44

Increase of white-tailed deer in domestication................. 45

Deer hybrids........................................ 45

Habits and management.................................... 46

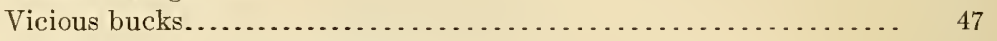

Capturing live deer for shipment........................ 48

Wild deer in private preserves............................. 50

Effect on game supply..................................... 51

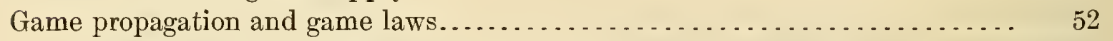

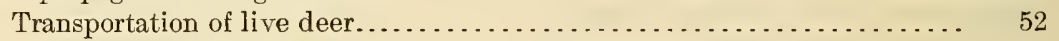

Transportation of venison.................................... 52

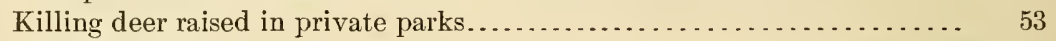

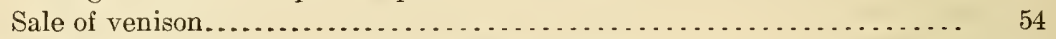

State laws recognizing private ownership of deer................. 55

Resolutions by the American Breeders' Association................... 58

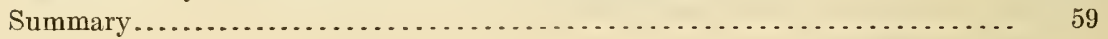

\section{ILLUSTRATIONS.}

Puage.

II. Elk in the Nationalec.

III. Fig. 1. Feeding time on farm of C. H. Roseberry, Stella, Mo. Fig. 2.

Mule deer, National Zoological Park, Washington, D. C....... 20

IV. Elk in new pasture, near Eureka Springs, Ark.............. 34

V. Elk park in the Ozarks, showing elimination of underbrush....... 34

VI. Tame elk on Indian Rock Game Preserve, owned by C. D. Richardson, West Brookfield, Mass......................... 36

VII. Virginia deer in park belonging to Thomas Blagden, Saranac Inn, Upper Saranac, N. Y . . . . . . . . . . . . . . . . . . . . . .

VIII. Fawns of the Virginia deer at Kent Deer Park, home of C. H. Rose-

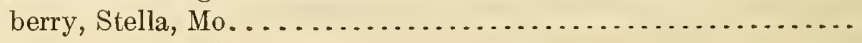




\section{RAISING DEER AND OTHER LARGE GAME ANIMALS IN THE UNITED STATES.}

\section{INTRODUCTION.}

Under present conditions in the United States, game animals of most kinds are rapidly diminishing in numbers. As game becomes scarcer, legal restrictions upon its pursuit and capture are of necessity increased to avoid complete extermination. Even after game is legally killed, the laws of some States make it impossible for the nonresident hunter either to carry the meat home to his family or to sell it. In the zeal for protecting our fast vanishing game animals, laws have been enacted which, unless modified, will hinder or permanently prevent the most important movement for game preservation yet tried in this country; namely, the propagation of game animals, not by the State alone, but by private enterprise as well.

A few States have recently modified their game laws so as to permit, under limitations, the sale of game from private preserves; but in many States restrictive laws still prevent the grower of such game from marketing it outside the State in which it is produced, or within the State except sometimes during a short open season. Complaint is made that our game laws favor sportsmen of means and are unfavorable to the farmer and to those citizens who, while themselves debarred from the pleasures of the chase, would like occasionally to have game on their own tables. If they could purchase venison grown in preserves, it would remove cause for complaint, and the traffic could be so regulated as not to hinder but to aid the protection of wild game.

It is here urged that if the natural resources of the country are the heritage of the people, they should be conserved for the benefit of all. If private enterprise can help in game preservation, it should be allowed to profit from investments. The propagation of game is as legitimate a business as the growing of beef or mutton; and the producer should be permitted, under reasonable regulations, to dispose of his product at any time, either for breeding purposes or for food.

The present bulletin discusses briefly the importance of domesticating wild mammals and the economic objects to be gained by the process. It calls attention to the species, especially those of the deer 
family, most promising for experiments in meat production, and relates successful experience in different sections of the United States with the wapiti, or Rocky Mountain elk, and with the Virginia deer. It discusses the relation of game laws to the business of growing venison-a business which, it is believed, with proper encouragement may be made highly profitable, especially since it will be the means of utilizing much otherwise unproductive land.

\section{IMPORTANCE OF DOMESTICATING MAMMALS.}

The question of practical benefits to be derived from domesticating more species of mamm.ls than we now have is by no means settled. It is claimed by some that the present list of domesticated kinds is ample for all economic requirements of the human race; that, so far as beasts of burden are concerned, we already have enough suited to every necessity; and, furthermore, that mechanical ingenuity is fast bringing us to a time when fewer kinds will be required. As to food animals, we are told that the excellence of our beef, pork, and mutton leaves nothing further to be desired. For clothing, it is said that the wools and hairs produced by mammals already under domestication amply supplement the vegetable fibers.

On the other side, we have the argument advanced by the French zoologist, E. Trouessart, to the effect that mankind should now make every effort to domesticate as many species of mammals as possible. He argues that in the course of time the extensive use of electricity and machinery must inevitably exhaust the coal, petroleum, and natural gas from the earth's crust, and that mankind will again be forced to rely largely upon the labor of animals. He urges immediate action because of the imminent danger of extermination of some of the species. ${ }^{a}$

Between these opposite views a middle ground may be maintained. Admitting that we have enough beasts of burden and as great a variety of animal food as the actual necessities of man demand, we still find excellent reasons for desiring to increase the number of species under domestication. While it is neither necessary nor desirable to domesticate every mammal possible, the field for choice. is large. Preliminary to choosing a species its ultimate usefulness must be considered. In reply to the oft-repeated argument that it takes so much time to develop a domestic species that the probable economic advantage will be overbalanced by the enormous expense required, it is enough to recall the fact that many wild animals show remarkable adaptability to the conditions imposed by domesticity. Canada geese, for instance, reared from the eggs of wild parents and kept with barnyard fowls show hardly any trace of wildness.

a. Bulletin de la Société d'Acclimatation for 1900, pp. 33-52, 1900. 
Young mammals of various kinds when caught wild and reared in captivity become absolutely tame and tractable. If these tame individuals can be bred successfully, there would seem to be few obstacles in the way of domesticating the species.

However, the problems of domestication are not quite so simple as the above statement might imply. It must be remembered that captivity and changes of environment often make wild animals peculiarly susceptible to disease. These and other considerations complicate the problems, whose solution, after all, will depend mainly upon the patience of the experimenter.

In considering the reasons for domesticating wild animals and plants, the rsthetic one should not be overlooked. A large number of the species that have come under human control have been tamed for the pleasure they afford to their owners. This is true of flowering and other ornamental plants, and of some birds-for instance, the canary. Probably this consideration always has weight in the selection of species and individuals for breeding, and it must have a marked influence in deciding the fitness of wild species of mammals for domestication.

Experiments in breeding wild mammals need not necessarily be with a view to complete domestication. The animals may be bred in inclosures giving sufficient range and a habitat as nearly natural as circumstances will permit, and the problems of ultimate domestication may be left for future determination. By this means the practical economic results of full domestication may be largely anticipated before the completion of the process, and the dangers incident to close captivity may be happily avoided.

The chief practical objects to be sought by breeding wild mammals in captivity are: (1) Preservation of species, (2) use in agriculture or transportation, (3) use for hides and fur, and (4) use for food.

\section{PRESERVATION OF SPECIES.}

The rapacity of man has often threatened the existence of valuable animals. The danger of extinction of the American buffalo, the African elephant, the eland, the walrus, the sea otter, and other species is not imaginary. Within recent times several species of birds have been lost to the world. Of mammals the quagga and the blaubok (Hippotragus leucophous), the latter a small relative of the roan antelope, have been exterminated in South Africa. Foresight might have preserved them, and foresight, aided by governmental intervention, will be needed to prerent the loss of many of the larger game animals of the world. Their preservation is in itself a sufficient reason for attempting their partial or complete domestication.

$63030^{\circ}-$ Bull. $36-10-2$ 


\section{USE IN AGRICULTURE AND TRANSPORTATION.}

The need of more kinds of beasts of burden is not great. The horse will never be surpassed in general usefulness in this capacity, and the other animals used in agriculture and commerce are excellent in their places. However, there are parts of the world where for special reasons the domestication of species of the native fauna might be of immense advantage to the people. The zebra and the elephant for Africa and the caribou for arctic America are examples.

\section{REARING MAMMALS FOR THEIR FUR.}

An important object to be attained by the rearing of wild mammals is the permanence and increase of our supply of furs. The growing scarcity of the better kinds of fur and the consequent high prices make the problem of domesticating fur-bearing animals of immense economic importance, while present conditions promise good returns to those who solve it. The beaver, the otter, the marten, the mink, the silver-gray fox, and the blue fox are among the mammals whose partial domestication and successful breeding would prove profitable.

\section{REARING IMAMIMALS FOR THEIR FLESH.}

From the economic point of view, the strongest argument for breeding mammals in captivity lies in their utility as food. For successful game propagation a less degree of domestication in mammals will suffice than when they are reared for fur or for use in agriculture and transportation. This circumstance greatly favors the game propagator. Besides, there is little probability that breeding game as an industry will ever be orerdone; the demand for the product is likely to keep pace with the supply.

\section{SELECTION OF SPECIES FOR REARING EXPERIMENTS.}

The larger game quadrupeds are the first to suggest themselves as suitable for propagation for food. The majority of our domestic mammals belong to the order of hoofed animals (Ungulata), and of these the most valuable food species are in the cloven-hoofed division (Artiodactyla). Pigs, goats, sheep, and oxen belong to this suborder; and to the wild members of this group we naturally look for additions to the list of domestic food animals."

The number of animals available for rearing experiments is quite large; but from any complete list of those adapted to a particular country a number of promising species would be rejected as superfluous. As a rule the kinds native to a region should have first consideration, since they need no acclimatizing. The selection of a foreign species for breeding must depend upon a similarity between its natural and its proposed habitat or upon its probable adaptability to 
the new environment. Adaptation may sometimes be judged from the history of former attempts to acclimatize it or its near relatives. In a country so extensive and varied as the United States the same principles should be considered before transferring a native species from one locality to another.

Some of the large game mammals whose partial domestication in the United States has been favored are briefly considered under the following subheads:

\section{THE PRONGHORN, OR AMERICAN ANTELOPE.}

The pronghorn (Antilocapra americana) is a game animal not closely related to any other living form. While its general characters ally it, as well as the antelopes of the Old World, to the cattle and sheep family (Бovidæ), it differs from other living ruminants in its deciduous and forked horn sheaths, and is usually considered as the type of a distinct family.

A half century ago the range of the pronghorn in the plains region extended from the valley of the Missonri River westward to the Cascades and from the Saskatchewan in latitude $53^{\circ}$ north, southward to the Mexican border. In Mexico the species is represented by a paler local race. The eastern limit of the original range of the antelope is not definitely known. According to Baird it was abundant in Minnesota on the plains of the Red River in $1850,{ }^{a}$ and it still occurred in the southwestern counties of that State in the early eighties. Pike found it common in eastern Kansas in 1806. The statements of the explorers of the plains indicate that it was about as abundant as the buffalo, although not seen in such vast herds.

The present distribution and numbers of the pronghorn are a sad commentary upon earlier game protection in the West. A few fugitive bands are now to be found in the cattle country from longitude $101^{\circ}$ westward. The story of their decrease in all of the States is practically repeated in the statements of D. C. Nowlin, state game warden of Wyoming, in his annual report for 1906. He says that antelope have decreased to an alarming extent throughout the State; for instance, in three years the Green River herd had diminished from about 6,000 to less than 2,000 head. Hundreds had perished through lack of food during storms, by depredations of wild animals, and through slaughter by Ute Indians. He repeats the recommendation of previons reports that the legislature should prohibit all killing of antelope for a term of years.

In 1909 the legislature of $\mathrm{W}$ yoming at last heeded the repeated recommendations of the game warden by passing a law protecting

${ }^{a}$ Report U. S. Com. Patents (Agriculture) for 1851, p. 121, 1852. 
antelope until 1915. Two other States-Montana and Nevadapassed laws in 1909 protecting antelope indefinitely. Washington still has an open season, but the animals are practically extinct in that State. Three Canadian Provinces-Alberta, Manitoba, and Saskatchewan-have open seasons; and of these, Manitoba has had none of the animals for more than twenty years.

In the United States antelope are now protected in every State in which they occur. The close season in Arizona expires March 1, 1911; in Colorado, September 25, 1912; Kansas, March 13, 1918; New Mexico, March 18, 1914; North Dakota, January 1, 1920; Oklahoma, November 1, 1914; Sonth Dakota, January 1, 1911; Texas, July 1, 1912; Utah, March 11, 1913; and Wyoming, September 25, 1915.

Experience shows that the antelope does not do well in close confinement. In zoological gardens it is short lived and seldom breeds. Judge J. D. Caton made a number of efforts to raise antelope in his park at Ottawa, Ill., but the animals died within a year. ${ }^{a}$ Other breeders have had similar experience. The difficulty seems to be that of providing a natural environment. Judge Caton stated that the antelope loses its timidity sooner and more completely than any other wild animal whose domestication he had attempted. "When taken young it soon acquires the attachment of a child for the human species, and when captured adult in a short time becomes so tame that it will take food from the hand, and follow one by the hour walking through the grounds." None of Judge Caton's antelope bred, and he concluded that the climate was too humid, and that his pasture lacked the vegetation essential to their health.

The experience of those who have tried to rear the antelope outside its natural range should not deter those who are favorably situated from undertaking further experiments with it. Visitors to Yellowstone National Park have been greatly surprised at the tameness of the antelope herds. Many western ranchmen have successfully reared the young. The animals were allowed perfect freedom, but could not be driven from the premises where they were fed. Reared in natural surroundings, unconfined, and with sufficient range, they would undoubtedly thrive and increase. In a few years by careful and continued taming of the young, one might secure a herd of absolntely tame antelope. Antelope require only a slight fence to confine them. They run very swiftly, but unless closely pressed will not jump an ordinary fence.

The flesh of the young antelope is said to be much superior to ordinary venison. That of mature animals, particularly the males, has a strong flavor; but this might be greatly improved under domesti- 
cation. A full-grown pronghorn weighs from 100 to 125 pounds, and will dress from 65 to 80 pounds.

\section{EXOTIC ANTELOPES.}

The Old World antelopes belong to the family of Boridæ, and include many raluable food animals. In Africa alone over a hundred species occur. many of them hardy and most of them excellent game. Fully a score of species would be promising subjects for acclimatizing in America. Africa, like our own country, has arid sections, and some of her antelopes are probably especially adapted to the desert lands of our Southwest, and might be used to restock parts of that region from which our own pronghorn has been exterminated. Some years ago a society was organized for the purpose of introducing the gazelle into southern California, but no practical results followed.

THE ELAND.

The eland (Taurotragus), the largest of the antelope family, is threatened with extermination over the greater part of its range in South Africa. Its a verage weight is from 800 to 1,100 pounds, and old males have been known to attain a weight of 1,400 to 1,500 pounds. This animal has often been recommended for rearing in captivity because of the excellence of its flesh, which is superior to beef. Harris, the African traveler, states that while it resembles beef in grain and color, it is far better flarored and more delicate, possessing a pure game flaror and remarkable for the quantity of fat interlarded between the muscles.

The eland was introduced into Holland by the Prince of Orange in 1783. It was acclimatized in England by the Earl of Derby in 1842, and was bred successfully in his parks. After his death the herd passed into possession of the London Zoological Society in 185̌1, and continued to increase in numbers for many years. In 1899 the Duke of Bedford had a fine herd of 14 elands in the park at Woburn Abbey.

The scarcity of this game animal in a wild state and the consequent cost of obtaining stock would probably make experiments in breeding it in the United States so expensire as to prohibit the attempt by individual enterprise. However, the experience with the animal in Europe gires assurance that, if properly undertaken, efforts to acclimatize it in the United States would be successful.

THE NILGAI.

The nilgai (Boselaphus tragocamelus) of India is, next to the eland, the largest of antelope. The animal is ungainly in appearance, and its flesh is somewhat inferior to that of the eland, but its 
size, its hardiness, and its lack of wildness commend it as a species suitable for domestication. It stands long droughts extremely well, and its flesh is equal to most venison in quality.

Nilgais were first taken to England in 1767. In 1862 a dozen of the animals were introduced into the park of Signor Comba at Mandria, Italy. In ten years the herd increased to 172 head. A small herd is kept by the Duke of Bedford at Woburn Abbey, England. In the National Zoological Park, the Philadelphia Zoological Gardens, and the New York Zoological Park these animals have done well and bred regularly.

SMALLER AN'TELOPES.

Some of the smaller members of the antelope tribe are excellent subjects for experiments in acclimatization and breeding in the United States. Among them are the gazelles of Asia and Africa, the duikers, the springbuck, and the roan antelope of Africa, and the Indian antelope, or black buck. Of the duikers (Cephalophus) there are over twenty kinds, ranging in size from that of a mediumsized donkey to that of a hare; and all are said to afford excellent venison, while some of them are known to be easily tamed. The Indian antelope, or black buck, has been bred in many zoological gardens, and a herd is kept in the park at Woburn Abbey. It is easily tamed, but, as is the case with many deer and antelope, the tame males become ill-tempered in the pairing season. In the Philadelphia and New York Zoological parks these animals have thrived and increased rapidly.

\section{IMPORTANCE OF THE DEER FAMILY.}

The deer family (Cervidx) stands next to the cattle and sheep family (Bovidæ) in general utility. The flesh is a valuable food, while the antlers or horns, as well as the skins, are important articles of commerce. Venison was more common than beef on the tables of medieval Europe, and was the flesh most commonly eaten by early settlers and frontiersmen in North America. Its dietetic value is enhanced by the fact that it is especially adapted to invalids who require a nourishing yet easily digested food.

In a recently published table showing the time required to digest various foods, grilled venison is given first rank with boiled tripe and boiled rice, as requiring but one hour for complete digestion. Whipped raw eggs, boiled barley, and boiled trout, as well as asparagus and a few other vegetables, require an hour and a half. Grilled beefsteak and mutton require three hours for digestion, while grilled or roasted veal and pork require five hours, or even more. ${ }^{a}$ 
Except in a few species like the caribou, only male deer have antlers. Although these horns are deciduous, they are solid processes produced from the frontal bone, and have the physical as well as the chemical properties of true bone. They are of two general typesthose more or less broad and flat and those rounded in shape. Those of the flattened type are usually the more massive, but the rounded antlers of the wapiti are exceptionally heavy.

Deerhorn has several uses. It produces much gelatin by decoction, the product being like that from most animal substances. The raspings and waste pieces of the horns used in manufacturing knife handles are either made into gelatin or boiled down into size used in cloth manufacture. At one time deerhorn was a prominent source of ammonia.

The principal use of deerhorn is in the manufacture of handles for knives, forks, and other instruments. In Sheffield, England, some thirty years ago, about 500 tons of deerhorn were used annually in manufacture. India and Ceylon furnished about four-fifths of this material, while about 100 tons came from European and English deer forests. The 500 tons represented the antlers of fully 350,000 deer of various species. $^{a}$ In Europe buckhorn is worked up into many useful articles, as umbrella stands, chandeliers, and ornaments for personal wear.

The use of deerskins is well known. As tanned and dressed by the American Indians they are manufactured into a variety of useful and ornamental articles. The inhabitants of some of the Indian villages of the North derive a good income from their manufactures of deerskins into moccasins, rackets, toboggans, and other things for sale. Deer hide makes an excellent leather, its value depending upon the size as well as upon the species from which it comes. The skins of wapiti, for instance, are porous, and the leather does not wear well, while those of the moose and European elk are so thick and hard that the leather is said to have resisted musket balls. In Sweden in former times a pair of elk-hide breeches went as a legacy through several generations of peasants. Formerly about 200,000 deerskins from North America were sold annually in the London market. Half of these were skins of the wapiti. Many were bought for Germany and there manufactured into leggings, but the heavier skins were tanned and manufactured in England. In recent years the export of deerskins from America has fallen off greatly.

Deer hair has a peculiar cellular structure, and is used in some parts of the world for stuffing saddles, for which purpose it is especially suited. 


\section{NATIVE DEER OF NORTH AIMERICA.}

North America is comparatively rich in species of deer. All of them are valuable food animals, and nearly all have been of great commercial and economic value during the development of the country. While their commercial importance has been greatly lessened as their numbers diminished, they still play an important part in furnishing food in newly settled parts of the United States and Canada, as well as in feeding the native tribes in the far North. Except in States that have extensive forested areas and have protected deer for a series of years, they are rapidly disappearing before the encroachments of agriculture. The remnant are valuable chiefly because they are a natural resource which may' be indefinitely developed if carefully husbanded. It is believed that with partial domestication and careful management in state and private game preserves, deer of most of our species may again become abundant. Considering the difficulties, attempts to domesticate them have been fairly satisfactory.

THE CARIBOU.

Several species and local races of the caribou, or reindeer, inhabit the northern part of North America. According to habitat, they fall naturally into two groups. The more northern, ranging beyond the forests, is best represented by the barren-ground caribou (Rangifer arcticus). The second group inhabits the forested area south of the other, and its most important representative is the woodland caribou (Rangifer caribou). Although they differ little from the wild Old World reindeer (Rangifer tarandus) in habits and general appearance, no attempts to domesticate the American reindeer seem to have been made. The larger woodland caribou is said to be exceedingly wild and timid, and for this reason its suitability for domestication has been questioned. The barren-ground species, although small, appears to be much less wild.

Prof. S. F. Baird was strongly of the opinion that American caribou of both groups are as capable of domestication as the European species, and he suggested that such a step would be of vast benefit to Indians of the North. Its success would at once place these people beyond the vicissitudes which are so rapidly sweeping them off. In the end they might "become a pastoral people, and possibly, in time, as agricultural as the nature of the seasons would admit." $a$

In the same paper from which the above quotation is taken Professor Baird suggested further that the domesticated European reindeer might itself be successfully imported and propagated in North

a Report U. S. Com. Patents (Agriculture) for 1851, p. 108, 1852. 
America, and that thus the loss of time in attempts to domesticate a wild species might be avoided. After the purchase of Alaska by the United States, the introduction of firearms among the natives led to such slaughter of game that actual starvation threatened some of the tribes. In 1887 Charles H. Townsend advised that the Government should import the reindeer and teach the natives how to care for and use the animals. In 1891 the late Dr. Sheldon Jackson, general agent in Alaska of the Bureau of Education, aided by donations from private sources, purchased a small herd of reindeer abroad. They arrived in Alaska in 1892. Since 1894 Congress has made annual appropriations for continuing the experiment. Up to and including 190t, the total number of reindeer imported from Siberia and Scandinavia was 1,280 , and at that time the herds numbered over 8,000. The net annual increase since importations ceased has been about 25 per cent. In 1907 the herds numbered 15,839 animals and the present number is probably not less than 23,000. The introduction of these animals has already proved to be of immense benefit to the natives, who have been taught how to manage them by herders from Lapland and Finland, brought to America for this service.

Through the efforts of Doctor Grenfell, Lapland reindeer have recently been introduced into Labrador and northern Newfoundland, and the experiment promises great success. W. J. Carroll, of St. Johns, Newfoundland, in commenting on the work of Doctor Grenfell, says:

"It is to be hoped that the introduction of reindeer will be the first step toward the domestication of our own caribou. With a quarter of a million of caribou running wild in the interior, increasing at the rate of 10,000 yearly, it will be seen that when Newfoundland wakes up to the possibilities of its caribou herds we will not only be able to have thousands of deer for commercial purposes, but also will have enough to keep this island a paradise for hunters when hunting big game on the continent becomes a thing of the past. As an instance of how they increase and multiply, Doctor Grenfell thinks his herd will be increased by 200 fawns this spring." a

While the domestication of the American caribou has been made less important by the introduction of the reindeer, good reasons for breeding the native animals still remain. They would probably be especially useful for crossing with the Old World species. The cross with the woodland caribou would doubtless produce animals of greater size and strength, and the native caribou could constantly be drawn upon for new blood, just as has often been done in the case of the wild reindeer of northern Europe and Siberia.

${ }^{a}$ Forest and Stream, LXX, 611, April 18, 1908.

$63030^{\circ}-$ Bull. 36-10-3 
THE MOOSE.

The largest living animal of the deer family is the moose, represented in America by a widely distributed species (Alces umericana). The Alaskan moose, on account of its great size, has been described as a separate species (Alces gigas). The European elk (Alces machlis) differs but slightly from the common moose of North America.

The moose is still found in some of the wooded parts of Canada, from Nova Scotia and New Brunswick to Manitoba, its range extending into the United States in northern Maine, Michigan, and Minnesota. In the Rocky Mountain region it ranges from northwestern Wyoming northwestward into Alaska. It is still fairly abundant in parts of Alaska and in British Columbia. Under a careful system of protection moose have slowly increased in numbers in Maine. A promising attempt has been made to reintroduce them into the Adirondacks, where they were exterminated nearly fifty years ago.

Perhaps no other American deer is naturally so well adapted to domestication as the moase. Professor Baird relates that a pair of the animals were kept by a man living near Houlton, Me. These had been trained to draw a sleigh, "which they did with great steadiness and swiftness, subject, however, to the inconvenience that, when they once took it into their heads to cool themselves in a neighboring river or lake, no effort could prevent them." a Audubon relates another instance of a moose's being trained to draw a sleigh. We are informed by a number of writers that the European species was in former times fully domesticated in northern Scandinavia and, like the reindeer, was used to carry couriers from place to place. They were swifter than reindeer and have been known to draw a sleigh 234 miles in a day. It is said that this use of elk was finally forbidden under heavy penalties on account of their having been employed to facilitate the escape of prisoners or suspected criminals, and the domestication of the animals was consequently abandoned.

Dr. W. T. Hornaday says of the moose that in captivity "it is docile; not foolishly nervous like most deer, but steady, confiding, and affectionate. Moose are easily handled and trained to drive in harness, and in contact with man manifest more common sense than any other species of deer with which I am acquainted." $b$

In spite of this natural tendency to tameness, the efforts that have been made to keep moose in confinement have nearly all failed. A pair were kept in the Cincinnati Zoological Garden for about five years, but this experience is exceptional. Dr. Hornaday expresses

${ }^{a}$ Report U. S. Com. Pateńts (Agriculture) for 1851, p. 115, 1852.

${ }^{b}$ The American Natural History, p. 141, 1904. 


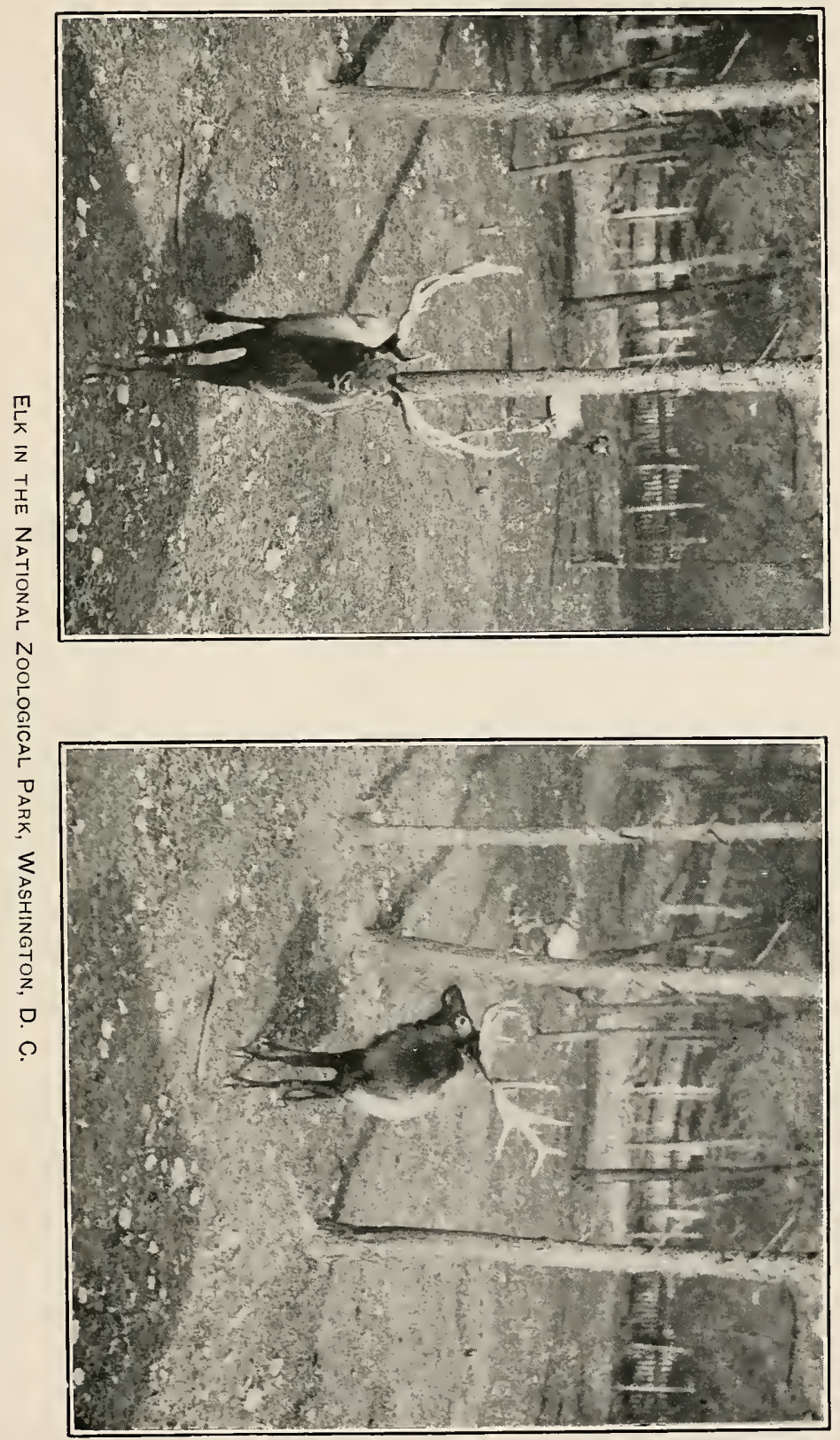



the belief that the failure is largely due to lack of vigorous daily exercise, which he thinks vitally necessary for the proper digestion and assimilation of their food. ${ }^{a}$ Others have suggested that most of the experiments have been made ontside of the natural range of moose, and that the climate was too warm for them. On the other hand, individual moose reared away from the parent cow have done well as long as they had the freedom of the forest; and in large preserves, such as the Blue Mountain Park in New Hampshire, the animals are said to thrive and increase. The difficulties in the way of raising them within their natural range are by no means insurmountable, and the practicability of breeding them when confined to forested areas within the Canadian life zone has been proved.

\section{THE WAPITI.}

The round-horned elk of North America are best represented by the Rocky Mountain wapiti (Cervus canadensis) (Plates I and II); but, besides the typical form, two species and a geographic race occur.

Next to the moose, the wapiti or elk is the largest American deer. Though not a true elk, the name has become too firmly fixed in our vernacular for change. This magnificent game animal was once abundant over a large part of the United States, and extended its range northward in northwest Canada to about latitude $60^{\circ}$ in the Peace River region. Southward it ranged to the southern Alleghenies, northern Texas, southern New Mexico, Arizona, and California. The limits of its range eastward were the Adirondacks, western New Jersey, and eastern Pennsylvania. Westward it occurred to the Pacific Ocean.

At present the range of the elk has so far diminished that, outside of the larger herds left in the Yellowstone National Park and the mountainous country surrounding it, the animals occur only in a few scattered localities. The herds in the national park and its vicinity are said to number about 30,000 head. Smaller numbers of the elk still occur in Colorado, Idaho, western Montana, western Oregon, northwestern California, and the Olympic Mountains in Washington. A remnant of the dwarf species of southern California is left in the upper San Joaquin Valley. Outside the United States, a few elk remain in southern Manitoba, Alberta, and on Vancouver Island.

In addition to the wild herds, a considerable number of elk are left in private game preserves and parks, as well as in nearly all public zoological gardens and parks of the United States. These form the nucleus from which, with good management, we may expect

${ }^{a}$ Hornaday, Wm. T., The American Natural History, p. 141, 1901. 
a restocking of some of the former ranges of the elk, and from which also a profitable business of raising the animals for market may be developed. At the present time no other member of the deer family seems to offer so promising a field for ventures in breeding for profit. Details of management and records of experience in breeding the elk will be given in another part of this bulletin.

\section{WHITE-TAILED DEER.}

The common deer of the United States is the whitetail, or Virginia, deer (Odocoileus virginianus). The species is widely distributed and, including the half dozen geographic races that occur within our borders, the range of this deer includes nearly all the United States, except large parts of Utah, Arizona, California, Oregon, and Washington. It is extinct in Delaware and practically so in several States of the Middle West; but it is still fairly common over the greater part of its original range. A number of nearly related species occur south of our borders.

The whitetail is the best known of om native deer and has been bred in semidomestication in many localities. Its suitability for parks is minquestioned, and in large preserves it increases very rapidly. It has not always done well, owing to diseases, but the difficulties in the way of rearing it successfully are not greater than those that attend the management of some of our domestic animals. Its habits and management are discussed later.

\section{MULE DEER.}

The mule deer (Odocoileus hemionus) (Plate III, fig. 2) is larger than the whitetail, and, thongh less widely distributed than that species, had originally a vast range on the western side of the continent. Including the six subspecies, or geographic races, it occurred from the Missouri River westward to California and southward into Lower California and Sonora. East of the Continental Divide its range extended north into British Columbia, Alberta, and other provinces to latitude $56^{\circ}$ or $57^{\circ}$, and south into Texas. This range has been greatly diminished by the encroachments of settlements and the lack of protecting laws, but the animals are still fairly common in scattered localities except in the open plains country.

Outside of its natural range the mule deer has seldom thrived. Indeed, many of the attempts to acclimatize it east of the Mississippi have failed. In zoological gardens the animals often die of diseases of the digestive organs, but in several places they do fairly well and have bred. They seem to have been thoronghly acclimatized in the large park belonging to the late William C. Whitney, 

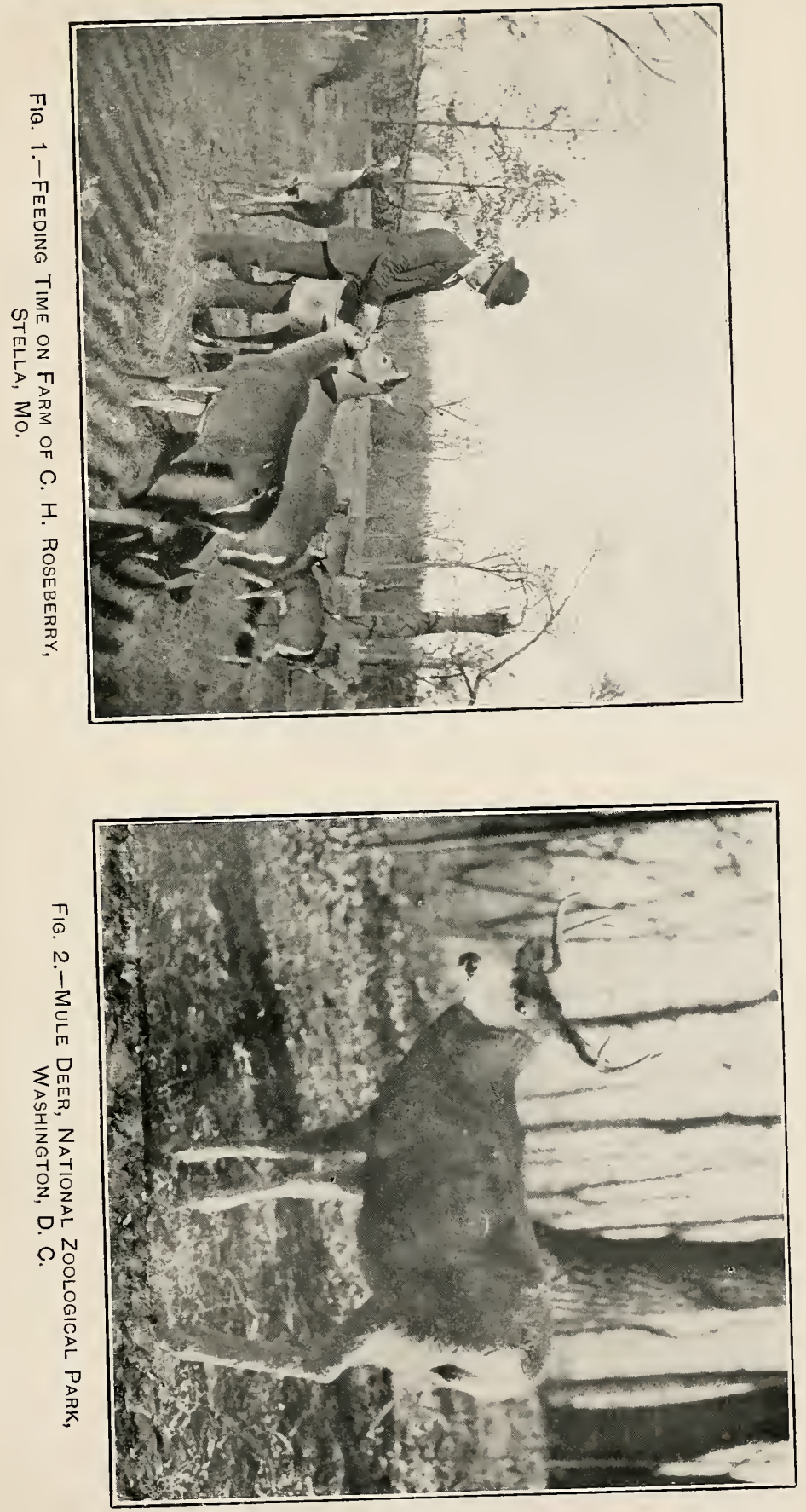

near Lenox, Mass., and they have bred regularly and done well in a small paddock at Crawfordsville, Ind.

The mule deer has been crossed with the Virginia and other deer, and hybrids with the southern Virginia deer have shown a superiority over that race in size and stamina. The hybridizing experiments already made give promise of an unexpected usefulness for the mule deer in captivity. Aside from the difficulty of acclimatizing it in humid regions, no unfavorable circumstances concerning it are known. It is prolific, its venison is excellent, and its superior size adds to its value as a market animal.

\section{COLUMBIA BLACK-TAILED DEER.}

The Columbia black-tailed deer (Odocoileus columbianus) is smaller than the mule deer or the typical Virginia deer. With its two geographic races it inhabits the Pacific coast west of the Cascades in northern California, Oregon, Washington, and British Columbia to southern Alaska. Although its home is in a humid country, it has resisted nearly all efforts to introduce it into the eastern United States, and the managers of zoological parks and gardens have about abandoned attempts to keep it. If not closely confined, it does well in parks and preserves within its natural range.

\section{EXOTIC DEER.}

Several species of exotic deer have been acclimatized in America; and, since the vast extent of our territory afiords a great variety of conditions, it is probable that many more species could be successfully introduced and bred in suitable localities. The red deer and the fallow deer of Europe seem to be well adapted to diverse climates, and are now to be found thriving in parks in many parts of the world, including the United States. A few other species whose habits and general usefulness commend them as excellent subjects for domestication are here named.

THE ALTAI WAPITI.

This wapiti (Cervus asiaticus) ${ }^{a}$ occurs in the Altai and Thian Shan mountains, and is one of the few deer that have been extensively kept in semidomestication. Large herds of these animals were formerly trapped in inclosures in the Altai Mountains and are kept in captivity for the sake of their antlers, which are cut when in the velvet and exported to China for use in medicine. About 6,000 of the animals are said to be in captivity, but owing to their destruction by hunters,

$a$ The proper scientific names of many exotic deer are in doubt. In this and one or two other instances the names here adopted are those used by Lydekker in his recent books on big game. 
wild wapiti of this species are now rare. Although this wapiti is smaller than the American species, the antlers are much larger. They sell at about 15 roubles $(\$ 7.50)$ a pound, and a single pair sometimes brings 120 roubles $(\$ 60){ }^{a}$

The Altai wapiti has been kept in parks in various parts of Europe, notably at Woburn Abbey, where the Duke of Bedford in 1896 introduced three stags and several hinds, purchased from Mr. Hagenbeck, of Hamburg. They have done well, but are in no way superior to the American wapiti, with which they interbreed. The Altai wapiti has bred in the Philadelphia Zoological Gardens.

THE JAPANESE SIKA.

Experiments in breeding the Japanese sika (Pseudaxis nippon) in Europe and America show that it is one of the most promising of the deer family for park purposes. It inhabits northern China, Manchuria, and Japan, but the Japanese race has been oftenest the subject of experiments in breeding.

One of the earliest to try this species in European parks was Viscount Powerscourt, of Powerscourt, in Wicklow, Ireland. In 1860 he purchased from Jamrach, the London dealer, a stag and three hinds and removed them to his estate, where they throve and multiplied greatly. In 1884, after twenty-four years of breeding and increase, his herd consisted of over 100 individuals, although 2 or 3 yearly had been shot, many given away, and others sold. Several deer parks in Ireland, England, and Scotland were stocked with this species from Powerscourt, and the animals thrived well in every place to which they were taken.

In 1879. Lord Powerscourt wrote:

Japanese deer require no care of any kind; they are as hardy as fallow or red deer, and the venison is as good. We had a hannch last year with more than 2 inches of fat on it. The haunches are small and of a handy size. ${ }^{b}$

Again, in 1884, he said:

These pretty little deer are the only [introduced] ones which hare multiplied, and have also never required any shelter of any kind, nor any winter feeding, except what the ordinary red deer and fallow deer get, such as hay, etc. *** * The Japanese deer here have undoubtedly interbred with the red deer; there are three or four deer in the park here which are certainly hybrids, the red hind in each case being the dam. The Japanese are a most satisfactory little deer; the venison when dressed is about the size of Welsh mutton and very well flavored. The little stags, with their black coats and thick necks, like miniature sambur, are very picturesque and ornamental, and I think they are a decided addition to onr varieties of hardy park deer. Some of them are always to be seen in the Society's gardens, but these give no idea of the beauty of the animals when in a wild state in a park. ${ }^{c}$

${ }^{a}$ Lydekker, R., Great and Small Game of Europe, Asia, and America, p. 67, 1901.

${ }^{b}$ Proc. Zool. Soc. London for 1879, p. 294, 1879.

c Proc. Zool. Soc. London for 1884, pp. 208, 208, 1884. 
Although the Japanese sika will take boughs when offered, it is chiefly a grazing animal. It is a rough feeder and thrives on the same food that cattle eat. The fact that it flourishes in the humid climates of Ireland and the Hawaiian Islands shows that it would probably do equally well in almost all parts of the United States. It has been successfully bred in most of the zoological parks of this country, and no obstacle to its successful propagation in open parks is known.

The Peking sika (Pseudaxis hortulorum) is larger than the Japanese species, much more vividly colored in summer, and, judging from the experience of the Duke of Bedford with his herd at Woburn, it also is admirably adapted for private parks in humid parts of our country.

THE PÈRE DAVID DEER.

The Père Darid deer (Elaphurus davidianus) is mentioned here because the species is now unlnnown in a wild state. When discovered by Père David none were known outside of the herds in the Imperial Park of the Emperor of China. The subsequent destruction of the imperial herds in 1894 left the fer individuals that had been taken to Europe, and their progeny, the only known living representatives of the species. It is now thought that the herd at Woburn Abbey are the sole survivors. They seem to be thoroughly acclimatized there and to be increasing from year to year.

INDIAN SAMBAR.

The Indian sambar (Cervus unicolor) is a large species with several geographic races. Although Lord Powerscourt failed to acclimatize these animals in his park in Ireland, they flourish at Woburn Abbey, where they are kept in the open. At Powerscourt the dense thickets and lack of sunshine were fatal to these deer. The species does well in zoological gardens and public parks, and it has often been recommended for private preserves. Like the wapiti, the male is vicious during the rutting season.

AXIS DEER, OR CHITAL.

The chital or spotted deer (Cervus axis) of India and Ceylon is one of the handsomest of ruminants. It is one of the few deer that is spotted with white throughout the year. The species has been successfully bred in European parks and in zoological gardens in many parts of the world. Although native to a warm country, it does well in England and the United States. At Woburn Abbey the herd is always in good condition. Its beauty makes it very desirable for parks. Unlike our native deer it sheds its horns irregularly and breeds at almost any season. It has been crossed with the Virginia deer. 
SMALL DEER.

The exotic species thus far mentioned are as large as our common deer, or larger. On our American farms and ranches, especially in the South, there is a distinct demand for a food animal of smaller size than the sheep for family use. A number of species of small Asiatic deer might admirably fill this want. Among them are several of the muntjacs (Cervulus) and the Chinese water deer (Hydrelaphus inermis).

The Indian muntjac (Cervulus muntjac) is probably the bestknown species of this genus. It is a beautiful little deer, with small horns, and stands 20 to 22 inches high. The animals live in thickets and tall grass, and are said to be solitary except when pairing. They are timid and seldom seen except when running away from beaters. When cornered they defend themselves with the long canine teeth and not with horns and hoofs like other deer. The period of gestation is six months, and two young are produced at a time. The animals feed like sheep on almost any herbage. They thrive in English parks and would probably flourish in our Southern States. The flesh is said to be excellent.

The Chinese water deer is less solitary in its habits, but in size and some other characteristics it is like the muntjacs. It is the most prolific of all the deer family, the female producing three or four young at a time. It is suited to marshy lands.

If any one of the various small species of deer or even antelope could be raised in the Southern States, it would furnish the farmers a much needed form of meat, which could be provided fresh every day or two as needed. Aside from fowls most of our domestic animals are too large for immediate consumption by the ordinary farmer's family. The successful introduction and breeding of a small mammal, in size intermediate between a hare and a sheep, would be of sufficient economic importance to warrant the expenditure of considerable sums of money in experiments. But this statement is true also of the domestication of any other deer.

\section{OBJECTIONS TO THE INTRODUCTION OF FOREIGN ANIMALS.}

In suggesting the acclimatization of foreign game animals, the Biological Survey does not advocate their indiscriminate introduction into the United States nor the immediate release of any of them to resume their wild life. The history of the introduction of beneficial animals into new localities should teach caution in such experiments. Even species fully domesticated have become injurious when neglected and allowed to run wild. Devastations of crops by horses, cattle, pigs, and goats, introduced into new countries for domestic use and afterwards abandoned, have been known in many parts of 
the world. The destruction of native birds and mammals by dogs and cats that have gone wild furnishes an equally valid argument for caution. Probably less danger attends the acclimatization and release of the class of animals under discussion than any other; and yet it is known that deer and antelope under certain circumstances have increased so enormously as to destroy important crops. Ordinarily should they prove injurious in the United States, the removal of protection would be followed by their speedy extermination as game.

\section{THE WAPITI, OR ROCKY MOUNTAIN ELK.}

HABITS.

In this bulletin the life history and habits of the Rocky Mountain elk are discussed only so far as they bear on the care and management of the animals in captivity or in game preserves.

On account of its size, the elk holds a place among American deer much like that occupied by the red deer among European Cervidx. Although a larger species, its general resemblance to the red deer caused early immigrants to apply that name to it. In New England, where there were no elk, the common Virginia deer was called the red deer. This confusion of names probably led to the adoption of the name elk for the wapiti because of its size. In view of its resemblance to the red deer so common in parks in the Old World, it seems strange that attempts to domesticate the wapiti in America were so long delayed.

The elk is both a browsing and a grazing animal. While it eats grass freely and can subsist upon it alone, it thrives best where there are also trees and underbrush. In its former range, when the surroundings permitted, it retreated into mountains and woodlands in summer, where it fed upon buds, twigs, leaves, and woodland grasses, while in winter it grazed chiefly in open prairies or glades, unless driven to timber by deep snows. The Wyoming herds summer chiefly in the high mountain pastures of the Yellowstone Park, and when these become covered with deep snow the animals retreat to the valleys southward and eastward of the park. They formerly ranged far out on the plains in winter, but intense summer grazing by cattle and sheep now leaves the winter pasturage too scant for them.

The American elk is extremely polygamous. The horns of adult bulls usually drop off in March or April, and new ones attain their full size within ninety days. The relvet adheres until about August, when it is gradually shed. The animals hasten the shedding by thrashing their horns against small trees and bushes. This is often referred to by hunters as "shaking," from the fact that the motion of the trees may be seen at great distances. The bulls usually lead solitary lives while the horns are growing, but early in September,

$$
63030^{\circ}-\text { Bull. } 36-10-4
$$


when the antlers are fully matured, the rutting season begins, and the bulls seek the herds of cows. Fights for supremacy then take place, and the victor takes charge of as many cows as he can round up and control.

In spring the cows remain in small herds until nearly time for the calves to be born. Then each seeks a secluded place, where she remains until the calf is strong enough to follow. In late summer the cows and calves begin to collect into small herds and are soon joined by the bulls. The period of gestation in the elk is from 249 to 262 days (average about $8 \frac{1}{2}$ months). The calves are born in May or June and, like the young of the common deer, are spotted, but the spots are not so nimerous nor so clearly defined, and they disappear in September with the first shedding of the hair. The female elk does not have young until three or four years old, and usually produces but one calf at a time. The calf follows the cow for a full year and sometimes even longer.

\section{ELK VENISON.}

The flesh of the elk is superior in flavor to most venison. The bulls are in best condition about the time the velvet is shed. By the time the rut is over, in October, the flesh is in the poorest condition. As the hunting season is usually in October and November and only males are killed, sportsmen often obtain the venison in poor condition, and, as a result, many persons have found fault with the flavor of elk meat. It is not best when freshly killed, but after hanging four or five days it becomes palatable and nutritious. Of course fat elk are better than lean, and it is said that the venison from castrated bulls is superior to that from others.

\section{PRESERVATION OF THE ELK.}

The preservation of the Rocky Mountain elk is of even greater importance than that of the American buffalo. While the destruction has not gone so far as in the case of the buffalo, absence of the elk from nineteen-twentieths of its former range is to be even more regretted. The buffalo was especially adapted to the prairies and the plains, and economically its place is better filled by the domestic cattle that now graze there. On the other hand, the elk is equally well, if not better, suited to rough, wooded areas not well adapted to cattle. Its preservation, therefore, may economically utilize such land, and the animals may become a valuable resource to the State as well as to the private owner.

The value of game to the State is seldom so fully appreciated that it is properly conserved and made to yield permanent returns. Maine probably secures the best value from its big game. Deer and moose 
in that State now pay a large part of the cost of game protection; the addition of a small resident license fee for hunting would make the actual revenue exceed considerably the cost of fish and game preservation. In addition, licensed guides earn about $\$ 360,000$ a year, while hotel keepers, railroads, express companies, and others derive greatly increased incomes from the sportsmen and tourists who are attracted to the State by its excellent hunting and fishing. Any State that has big game may profit by its preservation, and owners of private big game preserves should find them equally remunerative.

Its polygamous habit is a favorable factor in preserving the elk. The extermination of the buffalo was hastened by the fact that hunters, both white and native, preferred to kill the cows. Their flesh was superior to that of the bulls, while the robes they produced were of finer quality. In the course of time polyandry became so fixed among buffaloes that reproduction fell much below the normal rate. In the case of the elk, polygamy is the rule; and the destruction for trophies of males only, as well as the laws of States which forbid the killing of does, serves to perpetuate the species. The breeding of the animals is thus kept at a maximum rate.

The fact that elk congregate in large herds in winter has been unfavorable to their preservation. Pasture in their winter ranges is often insufficient for the demand, and the weaker animals perish. In recent year's, because of the encroachments of cattle and other stock upon the range, elk winter higher up in the mountains, where the snowfall is great. Poachers wearing snowshoes often approach and destroy an entire herd. Under adequate protection and with a proper supply of winter forage the gregarious habits of the elk would give increased security to the herds, but conditions hitherto have not brought about such results. On the contrary, wherever elk have been abundant much unlawful slaughter of the animals has taken place. Not only have nonresident hunters engaged in the business of killing them for heads, hides, and tusks, but residents of the game country have sometimes engaged in the same nefarious practice.

\section{WILD ELK IN THE EASTERN UNITED STATES.}

Probably the last wild elk of the original stock east of the Mississippi was killed in November, 1867, in Elk County, Pa., though possibly a few remained a little longer in the mountains of West Virginia. A few wealthy men have stocked private preserves with elk from the Rocky Mountains, and the experiment of acclimatizing them in the East has proved uniformly successful. A number of preserves in New Hampshire, Massachusetts, New York, New Jersey, Pennsylvania, and North Carolina have been noted for fine herds of these animals, the best known, perhaps, being those of Austin Corbin 
and William C. Whitney, both deceased. The Corbin preserve is on Croyden Mountain, near Newport, N. H., and the Whitney preserve was on October Mountain, near Lenox, Mass. At Mount Pocono, Pennsylvania, Carl Tielenius has a considerable herd of elk, kept on lands over which the wild elk ranged in the early part of the last century.

The New York Forest, Fish, and Game Commission have made in the Adirondacks the first systematic efforts in the East to restore elk to their former ranges. In June, 1901, the late William C. Whitney presented 22 head of elk-5 bulls and 17 cows-from his Massachusetts herd. This was followed in 1902 and 1903 by two gifts of larger herds from the same source and in 1906 by a gift of a herd of 26 from Mr. Corbin's Blue Mountain Forest Park, in New Hampshire. The elk were liberated in small bands at various places, mostly on state lands, and their increase has been satisfactory. It was estimated that on December 31, 1906, the total number at large in the Adirondacks was about 350 head. ${ }^{a}$ The elk, under proper protection, may be expected to become abundant again in the North Woods. The example of New York might well be followed by all States that have wild lands suitable for the elk. Pennsylvania has ideal places for the animals in her game preserves recently established, and all the States traversed by the Allegheny Mountain ranges have abundant wild lands for the introduction of the species. The cost of stocking with the animals would be slight compared with their ultimate value to the State. In New Hampshire there is reason to suppose that the beginning of a wild herd exists in animals that have escaped from the Corbin preserve. Forty-eight elk in one herd are reported to have been recently seen running at large in the forests. $^{b}$

\section{EXPERIENCE IN RAISING ELK.}

Although the American wapiti is less prolific than the common deer and some other species that have been bred in parks, it increases quite as fast as the red deer and is more hardy and easily managed. It has been successfully acclimatized in many parts of the world, and in England and on the Continent it has been crossed with both the Altai wapiti and the red deer. The hybrids in both cases were superior to the native stock in size and stamina.

The elk has been successfully bred in confinement in many parts of the United States, and in some instances has been domesticated. Audubon and Bachman say of it:

This species can be easily domesticated, as we have observed it in menageries and in parks both of Europe and America. The males, like those of the Vir-

${ }^{a}$ Field and Stream, XII, 59S. November, 1907.

${ }^{b}$ Recreation, XXVII, 129, March, 1908. 
ginia deer, as they advance in age, by their pugnacious habits are apt to become troublesome and dangerous. The elk lives to a great age, one having been kept in the possession of the elder Peale, of Philadelphia, for thirteen years; we observed one in the park of a nobleman in Austria that had been received from America twenty-five vears before. ${ }^{a}$

Professor Baird was of the opinion that the elk could easily be domesticated, and that, next to the caribou and the moose, it is the "one to which we are most entitled to look for an increase of our stock of domestic animals. The great size of the horns of the male; and his fierceness and uncontrollability during the rutting season, are certainly obstacles in the way of reducing the elk to the rank of a servant to man; nevertheless they are not unsurmountable, after all." He suggested that, as in the case of the buck of the common deer, castration would effectually subdue the animal. He suggested further that if the social instinct is necessary to the complete domestication of an animal, no deer possesses it in a higher degree than the elk, which is often found in immense herds. ${ }^{b}$

One of the earliest successful attempts to domesticate the roundhorned elk was made by Col. John Mercer, of Cedar Park, West River, Md. Colonel Mercer obtained his stock from St. Louis about seventy-five or eighty years ago. The animals were transported to Wheeling by water and thence to West River by way of Cumberland on foot. A few other breeders obtained stock from Colonel Mercer, among them Col. Joseph Tuley, of Millwood, Clarke County, Va.

Lorenzo Stratton, of Little Valley, Cattaraugus County, N. Y., began experiments with this species about sixty years ago. In a letter addressed to D. J. Browne, and dated January 12, 1859, he says :

The American elk, with all its claims to attention, is fast disappearing from the earth, with scarcely an effort for its preservation or domestication. By domestication I do not mean simply taming, but a course of intelligent breeding and protection. A series of experiments with this animal *** has furnished me with sufficient evidence to say confidently that this business may be made of great importance to the country. *** I have now a herd so gentle that a visitor at my farm would hardly imagine that their ancestors only three generations back were wild animals.

The facility for extending this business may easily be conceired. New York alone might support 100,000 elks on land where our domestic cattle could not subsist; furnishing an amount of renison almost incredible; while the adjoining State of Pennsylvania, to say nothing of other's, might sustain a still larger number without encroaching upon an acre of land now used for stock rearing, or any other purpose connected with agriculture. ${ }^{c}$

${ }^{a}$ The Quadrupeds of North America, II, 92, 1851.

${ }^{b}$ Report U. S. Com. Patents (Agriculture) for 1S51, p. 11S, 1852.

${ }^{c}$ Report U. S. Com. of Patents (Agriculture) for 1S5S, p. 237. 1859. 
At a meeting of the American Institute in New York January 6, 1862, Mr. Stratton gave a detailed account of his experience in domesticating the elk, in which he said, in part:

About eight years ago I had an opportunity to purchase two elks. I did so as a matter of curiosity and because I wished to see a few specimens of this forester preserved, as my place is situated in the region where they used to roam in countless numbers. They did well and bred. I fenced off a few acres for them, and found after a while that I could certainly raise venison cheaper than my neighbors could raise beef. I devoted a large plat of stony, bushy land, unfit for any other purpose, to them. Since then I have succeeded in breeding 37 elk. I have had no accident of any kind amongst them, and they have fatted and bred regularly and have become quite domesticated. The does have been gentle and act like domestic cattle. The bucks have been also gentle until they were about 4 years old, when they have been difficult to manage in September and October, like a bull or stud-horse. In such cases I generally made renison of them. Excepting these instances, however, the animals are quite docile. The first fawn that I raised was rely shy. He was in a lot of about 15 acres, and when I went to him he would flee from me, so that I could hardly get a sight at him. The next fawns raised were not so frightened when they saw me, and now when I go into the field the young fawns are like so many calres. My lot is fenced with common rails, 6 or 7 feet high, and there is no difficulty in keeping the animals within bounds. Frequently, when the fence may get dlown, they go out into a neighboring piece of woods, but as soon as anything startles them they run for their own field again, and feel safe only when they arrive there. They are not inclined to stray off. This lot in which they are confined they consider as their home, and chase off any dogs that may come upon it. In four generations, by kind treatment, I have, as I contend, not merely succeeded in taming them, but in domesticating them. They are as gentle as sheep that run wild. ***

* * * The great profit in raising them, however, is for their meat. They live and fatten on useless land. Where the feeding ground is brush they will destroy it; but the grass will come up more profusely on this account in the summer; and it has the result of giving them better feed in the summer though not so good in the winter. I paid $\$ 400$ for the first pair I bought; I have bought 2 does since then, from which, with the first pair, I have raised my whole stock; I have been at varions unnecessary expenses, from the fact that I did not know how to manage them; I can now raise elk cheaper than I can sheep; I have a 3-year-old buck, weighing 480 ponnds, which has cost me less than any 3-year-old sheep I have got. I have been anxious to introduce them as common stock and have sold them for $\$ 100$ a pair. A great many are afraid to buy them, for fear they will get away and go wild again. They see me go into the field and all the flock come about me, and each one tries to get his nose into my pocket; but they say, "I don't believe I could do that." 'They think there is some Rarey secret about it. When I go into the lot, I generally carry a little handful of salt, or grain, or something which they like, which makes them come about me. * * *

I think there is no better meat than that of the elk; it is richer and more juicy than the meat of the deer; I killed a 2-year-old doe this year which had had no fawn; she was very fat; I took 29 pounds of tallow from her, and she weighed $2 S 2$ pounds dressed, the skin weighing 28 pounds.

At the same meeting Mr. Trimble stated that several years previously, while traveling over the prairie in Illinois, he had seen at a 
house where he stopped a full-grown elk perfectly domesticated. There were no fences about and it never attempted to run away. ${ }^{a}$

The final outcome of the Stratton experiment at Little Valley was recorded in a communication to Forest and Stream by Mr. E. L. Stratton, of Grand View, Tenn., a brother of Lorenzo Stratton. He stated that so far as the experiment was carried it was a complete success. "Had there been a moderate amount of capital invested, with a larger territory of cheap mountain land added, and with close attention to the business, it would have been a profitable investment and doubtless would have shown handsome dividends. But when we decided to move Sonth, the elk business had to be abandoned. Most of the stock on hand was bought by some foreigners and shipped by rail to New York, thence some to Italy and the rest to Germany, and three or four were slaughtered at home." $b$

In 1887 T. D. Kellogg, of Whitestone, Long Island, contributed to the New York Herald an interesting account of his observations on domesticating the wapiti, made when a pioneer in northwestern Iowa in the fifties. Mr. Kellogg said that at that time elk roamed over all the plains of that part of Iowa, but already in diminishing numbers. In the spring when a settler had killed a doe elk he would occasionally take home a suckling fawn in his arms and bring it up by hand. Two settlers whom he knew well had each an elk thus domesticated, and several similar instances came to his knowledge. These settlers had no inclosure except a small garden patch, from which stock was excluded by a rude fence.

The tame elk, let loose upon the open prairie, were at full liberty, and although born in a wild state they never joined a passing herd nor roamed far from home. They gave no trouble by getting into the garden or injuring the fence. They were less timid than sheep, although not so familiar as dogs. "Probably no animal in existence," says Mr. Kellogg, "is naturally fitted to take so kindly to domestication as this noble creature, so rapidly disappearing from the face of the earth." $c$

Judge John D. Caton, of Illinois, who contributed so much to our knowledge of the deer family and of their susceptibility to domestication, seems to have been unfortunate in having inclosures poorly adapted to deer. He believed that his pastures contained some kind of vegetable food that was larmful to most of the species, but his clk were always healthy. Writing in 18s0, Judge Caton said:

My elk continue to do well and are so prolific that I have had repeatedly to reduce their numbers and would be glad now to dispose of at least 30 . I

${ }^{a}$ Trans. Am. Institute for 1861-62, pp. 220-223. 1862.

${ }^{b}$ Forest and Stream, XLVIII, 445, June 5, 1897.

$c$ The American Field, XXVIII, 126, August 6, 1887. 
have on an average about one old buck a year killed in battle and sometimes another by some casualty, but all appear healthy. Mine grow very large and of all the Cervidæ they seem best adapted to domestication. ${ }^{a}$

With few exceptions former attempts to rear elk were made by men who were wealthy and actuated only by a desire to possess or to preserve the animals. Care of them was left to servants. The bucks remained uncastrated until they became old and unmanageable, when the serious problem of caring for them soon outweighed the novelty of their possession, and the experiments were abandoned. This will account for the failure of many of the herds that were founded a half century or more ago.

But these breeders of the elk have not been without successors, and at present there are small herds of elk under private ownership in many places in the United States. The Biological Survey has recently opened communication with owners of herds of elk and deer, for the purpose of learning their experience in rearing the animals and obtaining their opinions as to the feasibility of making the business profitable. Extracts from recent correspondence referring to the wapiti, or ellk, follow:

Joshua Hill, of Pontiac, Mich., wrote, October 12, 1907, that he has elk and bison in his preserve of 300 acres. He finds the sale of elk meat slow, but thinks that, if properly pushed, the business of growing it would pay well. In his opinion the elk would be more profitable than deer, since the animals are larger and the venison better. He has heard of elk meat bringing 50 cents to $\$ 1$ per pound.

Isaac A. Bonine, of Niles, Mich., wrote, under date of October 14, 1907 , stating that he had been breeding both the elk and deer for about thirty-five years. He said: "We find that deer are not so hardy as elk and require more care. Elk require less care than the domestic animals, while deer are even more delicate. Deer should have a greater variety of food than elk. Elk winter well on hay and corn fodder with a little grain, and they live and thrive during summer months on blue grass. Deer will live on the foods mentioned here for elk, but they should have vegetables also. They require an open shed or shelter of some sort during winter; an elk requires none. The growing of both elk and deer for park purposes may be made profitable."

J. W. Gilbert, of Friend, Nebr., states (March 17, 1908) that he has been growing deer and elk for seventeen years. The deer have not always done well, but he now has a healthy herd of about 30 head. The elk have increased and done well all the time. He has never had a barren cow elk. Mr. Gilbert's range of 75 acres is on the open prairie, and contains buffalo, deer, and elk.

F. J. Wilson, of Lewisburg, Ohio, began raising elk and deer a few years ago, with three head of each at first. He has not succeeded so 
well with deer as with the elk. Deer require a higher fence and more care. The elk do well on hay, corn fodder, and other rough feed; if they escape from an inclosure they can be driven back like cattle. Mr. Wilson paid $\$ 165$ for 2 adult elk and a fawn. He has sold $\$ 300$ worth of stock, and, in 1908, had a herd of 12 head, worth $\$ 1,000$.

The experience of Carl Tielenius with his herd at Mount Pocono, Pa., is less satisfactory. He began about the year 1890 with 26 head of 2 -year-old elk, 22 of which were cows. The first year they produced 23 calves, and in the following four years $22,18,16$, and 12 , respectively. In later years with about 80 cows the number of calves has ranged from 5 to 10 per year. The herd is healthy, but reproduction is deficient in spite of the infusion of new blood by the introduction of bulls, from the Whitney herd. It is possible that, as Judge Caton suspected to be the trouble in his herd, the bulls at Mount Pocono exhaust themselves by much fighting before the rut begins.

\section{ELK IN THE OZARK MYUNTAINS.}

Col. W. C. Wetmore, of St. Louis, writes under date of April 20, 1908, that the St: Louis Park and Agricultural Company, of which he is a member, owns several thousand acres of land in Taney County, Mo. The land is in the Ozark Mountains and the ground rough and hilly, though well watered. A little of the upland and some of the valleys are tillable, and corn and oats are grown in the former and corn and alfalfa in the latter-enough to feed the game when snow prevents their finding their ordinary food. The preserve is surrounded with an 8-foot wire fence, and in it are now about 400 elk and 1,000 deer.

Colonel Wetmore writes further:

They are hearty and healthy and do well in every way and at all times are fat and marketable. I am thoroughly convinced that the raising of both elk and deer can be made very profitable where the ground, water, and other conditions are farorable. Deer increase very rapidly, as a doe usually drops twins after she is three years old. Elk do not increase so rapidly, cow elk dropping a calf every other year, but they are hardy, and with an experience of over twenty years I have not known one to die of natural causes. *** I am a lover of all wild game, particularly deer and elk, and I hope you will be successful in interesting people in propagating them. Give them plenty of room to run in and they will do well.

George W. Russ, of Eureka Springs, Ark., has a herd of 93 elk (1909). They have ample range in the Ozarks on rough land covered with hardwood forest and abundant underbrush. He reports that the animals improve the forest by clearing out part of the thicket. Fully 90 per cent of the females produce healthy young, and Mr. Russ thinks he could make the business of growing elk for market profitable if the law would permit him to kill and export the meat. 
He has an offer of 40 cents a pound for the dressed carcasses in St. Louis. If, as he claims, he can produce elk meat cheaper than beef, pork, or mutton, this should be a remunerative price. He thinks that large areas in the Alleghenies and Ozarks not now utilized could be economically adapted to produce venison for sale, and he regards the American elk as especially suited for forest grazing.

Mr. Russ, in a letter dated Eureka Springs, Ark., March 7, 1908, sent the Department of Agriculture, through H. N. Vinall, Bureau of Plant Industry, the following answers to the several questions propounded:

Question 1. How many acres per elk of forest land is needed for best results?

Answer. Much depends upon the character of the forest land. In this section of the Ozark Mountains an average of 5 acres to the head. In other sections a larger area will be necessary. The larger the area the better the results. One hundred elk will fare better in a 500-acre inclosure than one elk confined on 5 acres.

Question 2. Would it be possible for individuals to raise elk under grazing permits in large tracts like the national forests without fencing, by some method of feeding in a certain place or by herding?

Answer. We think it possible to raise elk by individuals having permits in the national forests, by a system of feeding in certain places, thereby locating these animals on the range best fitted for them, aud by loose herding by welltrained men familiar with their habits. But there are so many contingencies to be reckoned with on an open range that in our opinion it would be far preferable to fence.

Question 3. What is the cost per mile in forest land of an elk fence?

Answer. Again, much depends on distance from railroad, cost of labor, etc.; but ordinarily where posts and stays cost nothing but the making of them a good elk fence can be built for about $\$ 200$ per mile.

Question 4. Will the elk do any considerable damage to a forest in restricting the growth of young trees of valuable species?

Answer. Elk will feed on buds and leaves 8 feet above the ground, and any growth up to or under this is liable to be eliminated, depending upon the amount of such food. Unless the range is very much restricted they will not eat the bark from trees, neither will they resort to any species of evergreen. (Pl. IV.)

Question 5. What has been the per cent of increase in your herd under domestication?

Answer. The increase in elk under domestication is equal to that of cattle.

Question 6. What is the average weight of an adult male? Of a female?

Answer. Male, 700 to 1,000 pounds; female, 600 to 800 pounds.

Question 7. Will they not give a greater per cent of dressed meat than cattle?

Answer. Yes; but owing to the game laws our experience has been limited to a few animals. The per cent of dressed meat is much more. 


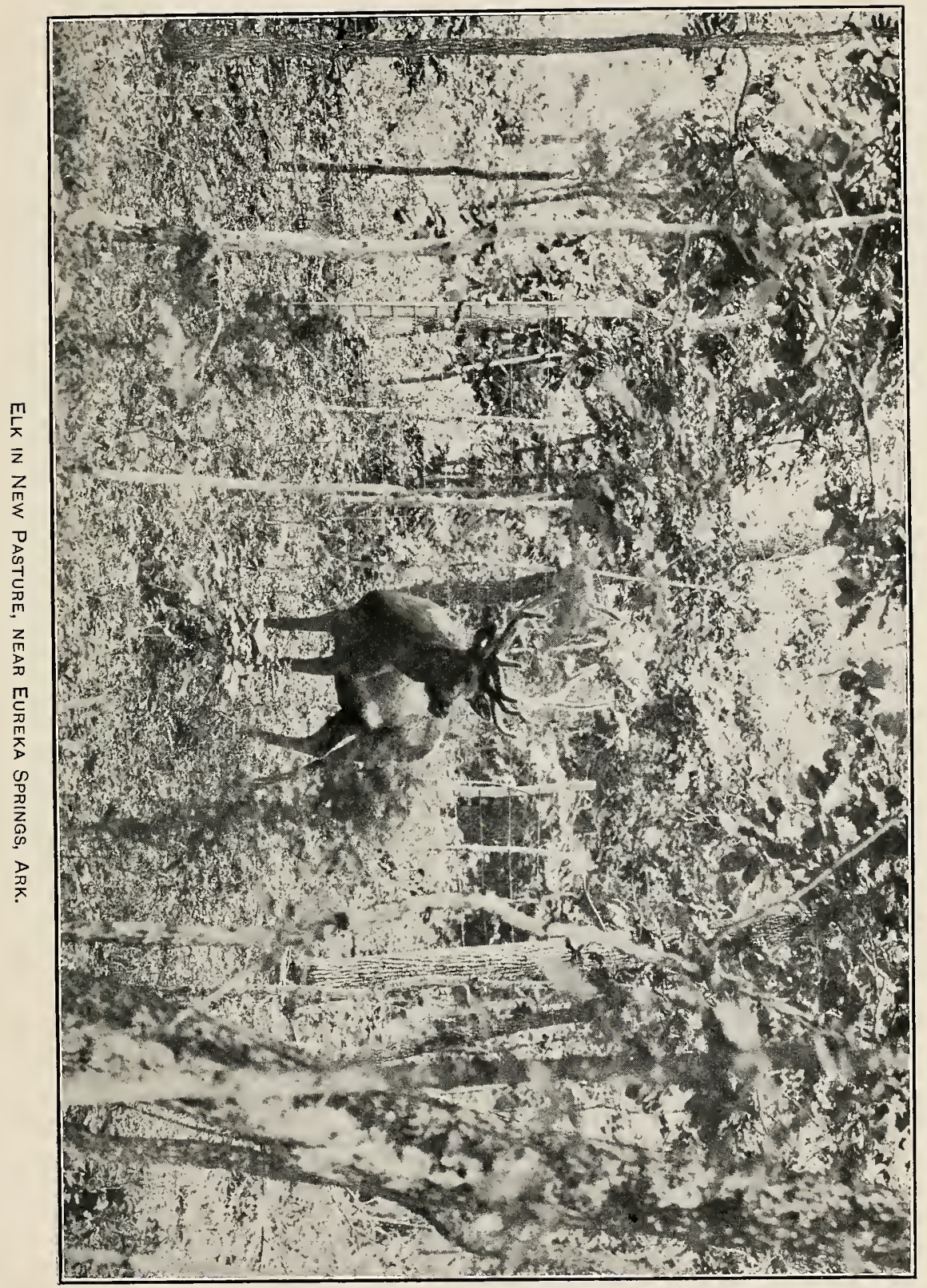





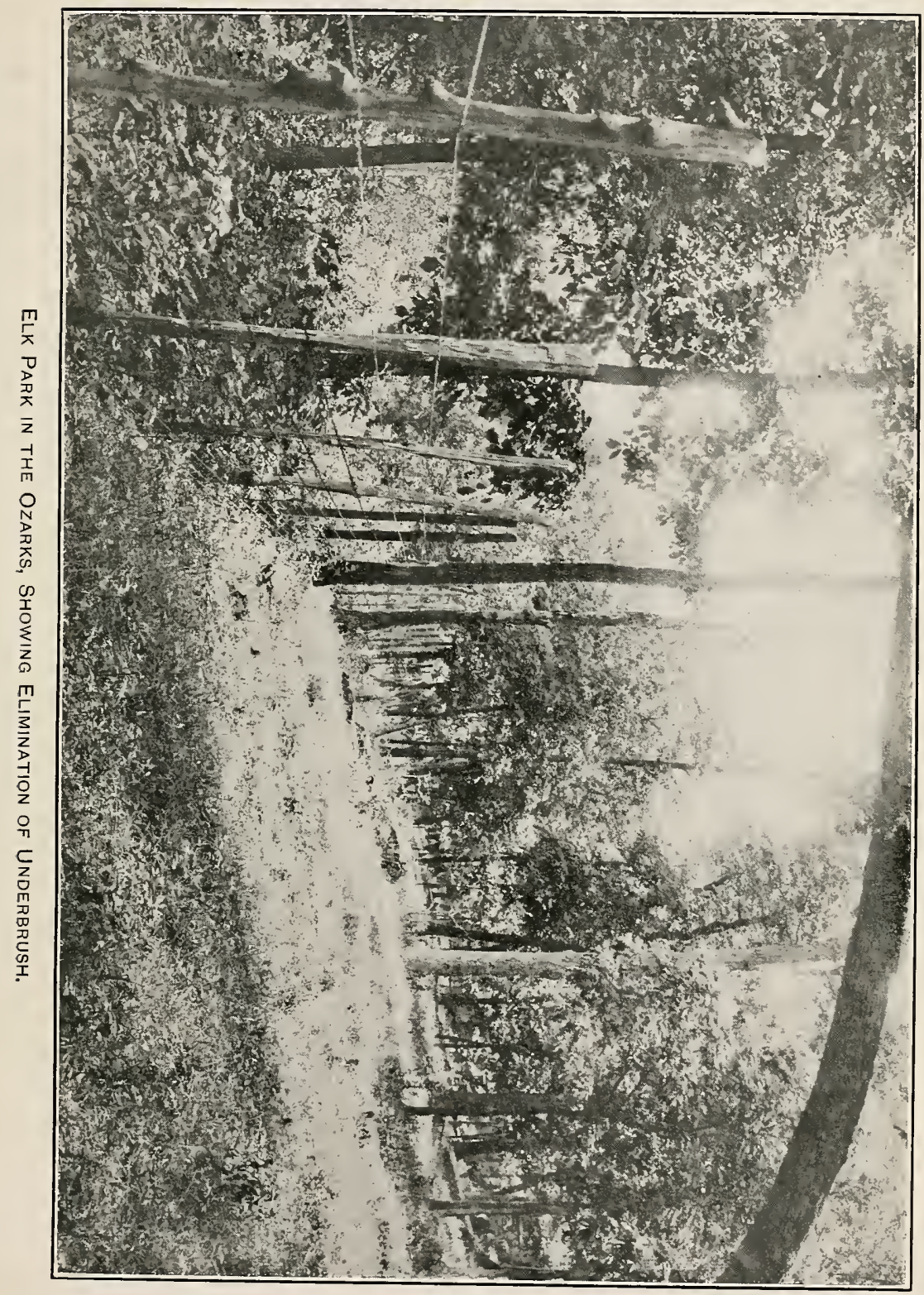



Question 8. Is there at this time, or would there be in ease the laws were revised, any general demand for elk meat? At what price?

Answer. In answer to this question, we can be guided only by the very limited demand, owing to the law prohibiting the sale of elk meat. We do, however, receive orders from parties not familiar with the law, and letters from many asking us if we are permitted to sell. From the fact that as high as $\$ 1.50$ per pound has been paid for this meat in New York City and Canada, and that the best hotels and restaurants pronounce it the finest of all the meats of mammals, we are of the opinion that if the laws were such that domesticated elk meat could be furnished it would be many years before the supply would make the price reasonable compared with other meats.

Question 9. What price per pound wonld you consider necessary to make the prouluction of elk meat profitable?

Answer. Elk meat can be produced in many sections of this conntry for less cost per pound than beef, mutton, or pork.

Question 10. What laws, state or national, at present interfere with the production and sale of elk meat? What are your recommendations for revising these laws?

Answer. The remedy to the state and national laws is very simple, and at the same time just and equitable. By simply adding or inserting the word "wild" before the name of the animal protected. To guard against abuses, a certificate from the owner of domesticated animals should follow them, and proper penalties should be imposed for any violation of the laws.

Question 11. Would the elk be adapted for browsing in the Appalachian forests from Pennsylvania south to Georgia?

Answer. Yes; I am quite familiar with the Appalachian range, and consider it ideal.

Question 12. Are they as useful as goats in clearing out underbrush? Is it best to use both goats and elk?

Answer. They are more nseful, as they will browse as low as goats and twice as high. I would earnestly recommend the use of both goats and elk for clearing up brushy land and fitting it for tame grasses. Elk and goats get along well in the same inclosure.

Question 13. What area will they clear up per year in your section? Keep cleared?

Answer. So much depends on the amount of underbrush as to the average amount elk and goats will keep cleared. The conditions in a mountainous country are much more diversified than in a level one, the growth of underbrush and timber often changing radically in a fourth of a mile. The average conditions in this range of mountains cau only be estimated approximately. Our experience has taught us that to get the best results, after stocking with elk and goats, it is best to wait one year before seeding, then continue with elk and goats two years more; when, if properly seeded and pastured, an open woodland pasture of tame grasses will be obtained (Plate V). To accomplish this, our estimate would be an average of one elk and two goats to 5 acres. When the underbrush and weeds have been eliminated by elk and goats, they will be very slow in coming in again. The life has been destroyed by the continued browsing on bud and leaf, and not only is the stem dead but the root also. The 
perennial weeds have been treated the same way. Those coming from seed must come from outside the fence, and will find the tame grasses in possession. Elk and goats fed on the falling leaves in the fall, thus lessening the covering of grasses. Tame grasses will not thrive under a thick coating of dead leaves.

Question 14. Is the forest open enough after their work to permit the growth of grass?

Answer. Elk and goats do not open up dense forests, except undergrowth. It is necessary to have considerable light and sun for the growing of tame grasses.

Question 15. After the forest land has been cleared and seeded to tame grass, could sheep be grazed in the same lot as the elk?

Answer. In reply to this question, we answer from long experience that cattle, sheep, and goats can be.grazed in the same lots with elk, providing, however, that the lots or inclosures are not small-the larger the area the better; and we know of no more appropriate place to call attention to the great benefit of a few elk in the same pasture with sheep or goats. An elk is the natural enemy of dogs and wolves. We suffered great losses to our flocks until we learned this fact; since then we have had no loss from that cause. A few elk in a thousand-acre pasture will absolutely protect the flocks therein. Our own dogs are so well aware of the danger in our elk park that they can not be induced to enter it.

In your note you invite us to suggest any other points not covered by your questions. Te think of nothing but feed and shelter. Nature has provided the elk with a winter coat of hair, which is in itself ample protection from any weather conditions, and which makes artificial protection unnecessary. All that is needed is feed, and on account of their browsing on that which is already in our hills and low mountains but little provision is needed. Like cattle, they are fond of grain and can be fattened on it, but may be kept in good condition during the winter on very little roughness. To be more explicit, one-half the ration per pound required for cattle will do for elk. TVe have opinions about caring for and domesticating the wild elk, saving to the nation what yet remains, and using them as a nucleus for general domestication and distribution. These views we will gladly furnish if desired.

\section{IIANAGEMENT OF ELK IN INCLOSURES.}

The experience of Mr. Stratton at Little Valley, N. Y., recounted in the preceding pages, gives an excellent foundation for practice in developing a true domesticity in the wapiti; but for economic reasons it may not always be possible for the raiser of the elk to adopt the same methods. He may wish to grow the animals for venison only and on large preserves where the calves can not be tamed when young. But when the elk is grown for stocking parks and private preserves, the tamer the herd the easier will it be to handle and ship the stock.

\section{RANGE.}

The natural food supply is an important consideration in choosing a range for the elk. While elk have done well in blue-grass pasture and on the prairie grasses alone, they do far better on preserves 


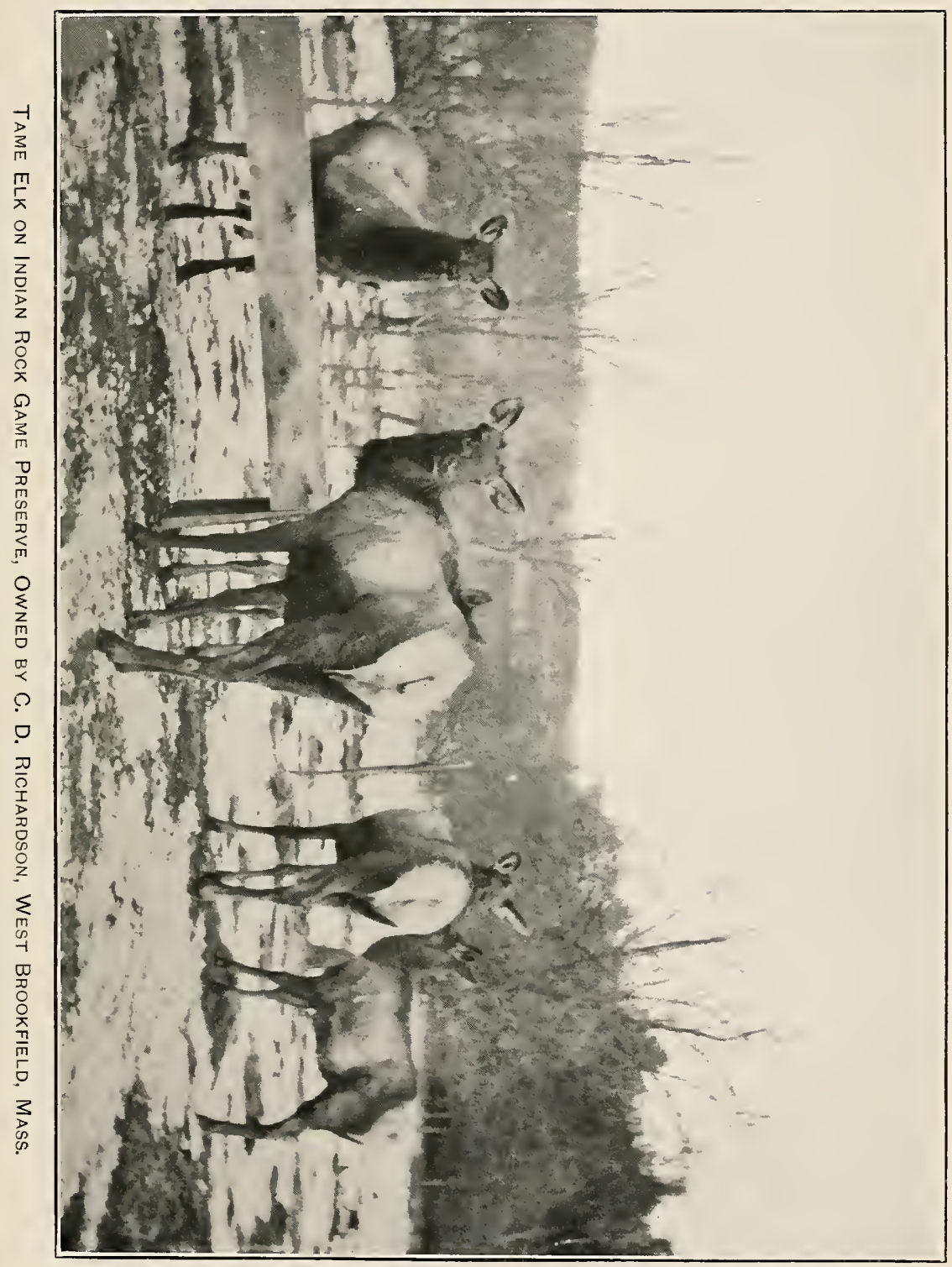



which have a variety of food-grasses, bushes, and trees. Rough lands well watered by streams and having a considerable proportion of forested area are best adapted to their wants. On an average such lands will support about the same number of elk as of cattle on the same area without impairing the range. There should be thickets enough to furnish winter browse for the animals. A supply of winter forage of other kinds will prevent the too rapid destruction of shrubbery in thickets.

FOOD.

Except in times of snow, elk will keep in excellent condition on ordinary grass pasture, but a system of management which regularly furnishes other food to the animals will be found better. For winter, hay and corn fodder furnish excellent forage; but alfalfa hay has proved to be the most satisfactory dry food that can be given to either elk or deer. A little oats or corn, whole or chopped, may be fed each day. Elk are fond of corn, and feeding corn and salt affords the best opportunities for winning confidence of the animals and taming them. Salt should be furnished liberally to all deer kept in inclosures. Running water, although not essential, is of great importance in maintaining elk in good condition. (Plate VI shows a small herd of elk at feeding place in winter.)

FENCE.

Elk are not nervous like the common deer and seldom jump an ordinary fence. A fence 5 feet in height is usually sufficient to confine elk, and Henry Binning, of Cora, Wyo., thinks a 4-foot wovenwire fence is ample. When they escape from an inclosure in which they have been fed they usually return of their own accord. Some herds may be driven like ordinary cattle. A small inclosure for a vicious bull elk should have a strong fence, 7 or 8 feet high. Mr. Russ tells us that where lumber for posts is cheap a good elk fence can be built for $\$ 200$ a mile, but the actual cost will, of course, vary greatly, according to style, cost of labor, nearness to market, and other eireumstances.

\section{COST OF STOCK.}

The cost of stocking an elk preserve is not great. Young elk in perfect condition may be bought for $\$ 100$ per head or less. A few years ago Mr. Wilson, of Lewisburg, Ohio, paid $\$ 165$ for 3 head. A Michigan breeder recently offered a dozen head, all fine specimens, but age and sex not given, for $\$ 500$. This is, of course, a low price, not more than cattle would bring, and less than the renison would be worth if they could be sold in that form. The price of such stock is determined by the law of supply and demand, and as long as the 
present restrictions on the sale of deer and elk are maintained, low prices are likely to prevail. Live elk sold at forced sale have been known to net the owners less than $\$ 25$ a head, but conditions would soon change if the laws concerning the sale and shipment of venison were generally made favorable for producing it in preserves. The demand for breeding stock would grow and increase the cost of starting, as well as the returns from the business. ${ }^{a}$

VICIOUSNESS OF THE MALE ELK.

Notwithstanding the riciousness of the male elk in the rutting season, he is ordinarily docile, probably more so than the buck of the common deer. Male ellk have frequently been trained to harness and driven in public. Lorenzo Stratton trained a pair to harness and began exhibiting them at the Cattaraugus County (N. Y.) fair in 1853. They were a feature of the fair for several years, until he sold them in Europe. Exhibitions of trotting elks were common at county fairs in the Middle West a few years ago. W. H. Barnes, of Sioux City, Iowa, trained a pair and drove them harnessed to a light vehicle. He afterwards taught one of them to dive from a platform 30 feet high into a pool of water, and later he exhibited the animal in this act to admiring crowds in Europe.

The intractability of the male elk is not exceptional among deer kept in confinement, but his great size, his long, sharp-pointed antlers, and his thick skin, that renders him insensible to pain, make him much more formidable than the common deer. Several tragedies connected with attempts to domesticate the elk are matters of history. One recorded by Judge Caton occurred in his park. ${ }^{b}$ Another took place at Bull City, Osborne County, Kans., October 12, 1879, in which Gen. H. C. Bull was instantly killed, two other men mortally wounded, and a fourth seriously injured by the attacks of an infuriated elk that had previonsly been regarded as tame and docile.

Deer and elk that are wild and unconfined will, under nearly all circumstances, run from man. When wounded they have been known to attack hunters; but it is unlikely that an uninjured wild bull elk would attack a human being even during the rut. The tame or partially tame animals that have become familiar with man are the ones to be feared. However, not all individuals become ill-tempered or vicious.

It should be borne in mind that all deer when confined in small inclosures and partly domesticated are likely to become dangerous

${ }^{a}$ Since the above paragraph was written Farmers' Bulletin No. 330, Deer Farming in the United States, has been issued, and an unusual demand for deer and elk for breeding purposes has developed. Consequently prices are considerably higher.

${ }^{b}$ The Antelope and Deer of America, p. 285, 1877. 
whether they have antlers or not. They can strike a vicious blow with the front feet; and a strong man, taken unawares, may easily be disabled or even killed by a doe of the common deer. To overcome the tendency to bad temper in deer would require many generations of breeding under domestication. It can not be quickly eradicated by petting the animals; on the contrary, it is usually increased by overfamiliarity. Children and strangers should be excluded from parks and paddocks that contain deer known to be vicious. Special precautions should be taken during the rut and when does have very young fawns. Persons with whom the animals are familiar should be constantly on the alert against surprise. In the rutting season no adult male deer or elk, however mild he may be at other times, should be trusted.

The remedy for viciousness in the male deer is castration. This makes the animal docile. It is unsafe to keep an uncastrated male elk over 4 years old, except in a strongly fenced inclosure. If the operation is performed when the horns are fully developed, they will be shed at the usual time and a new pair will take their place, but will not fully mature nor lose the velvet.

Another effect of castration is improvement in the quality of the meat, just as in the production of beef, pork, and mutton. Venison grown in preserves under a system in which all the male animals intended for slaughter are castrated should be uniformly of the highest quality, far superior to that obtained in the wild state during the usual open season for hunting, which comes during the rut or soon after. This is of great importance in fixing the final status of venison grown in private preserves.

THE ELI AS AN ENEMY OF IVOLVES AND DOGS.

The statement by Mr. Russ in his report on raising the elk in the Ozarks, to the effect that elk are enemies of dogs and wolves, is of more than passing interest. Judge Caton reported a similar animosity of his elk toward $\operatorname{dogs}$, and stated that the doeg always led in the chase of dogs that got into the elk park. If it is true that these animals when umhampered by deep snow will attack and vanquish dogs and wolves and thus help to protect domestic animals grazing in the same pastures, a knowledge of the fact may prove useful to stockmen and especially to sheep growers. It should be of great advantage in changing from a system of herding to the use of fenced pastures for flocks.

It is doubtful whether the enmity of elk for dogs and wolves extends to the animals outside of fenced pastures. Ex-President Roosevelt in Outdoor Pastimes of an American Hunter reports having seen a coyote walking unnoticed among a herd of elk in Yellow- 
stone National Park. Thomas Blagden, of Washington, D. C., informs the writer that elk taken from the Whitney preserve to Ipper Saranac Lake in the Adirondacks always ran from barking dogs, and were frequently chased from the grounds of cottages near Saranac Inn by this means; but possibly the presence of men with the dogs had much to do with the fleeing of the elk.

\section{THE WHITETAIL, OR VIRGINIA DEER.}

Since the whitetail is the most widely distributed of American Cervidæ, there can be no question of its adaptability to nearly all sections of the United States. Testimony as to its hardiness in parks and preserves is not so unanimous as in case of the wapiti; but the general opinion of breeders is that with suitable range, plenty of good water, and reasonable care in winter the business of raising the animals for stocking parks and for venison may be made as profitable as any other live-stock industry. It has the advantage that land unsuited for cattle may be utilized in raising deer.

Advocates of the Angora goat industry state that in the United States there are 250,000,000 acres of land not suited for tillage nor as pasture for horses, cattle, or sheep, which are well adapted to goats. Much of this land is equally well suited to deer and elk, which do less injury than goats to the forest cover.

Probably experiments in domestication have oftener been made with white-tailed deer than with any other North American mammal. The great beanty of the young fawns appealed to the earliest settlers, who soon learned how easily they could be tamed and how readily they attached themselves to those who fed them. The danger from these same pets, especially the males, when grown, was soon learned also. Thus the experiment usually ended with the maturity of the subject, which was soon disposed of or banished to a safe inclosure.

Deer parks were established in early times on a considerable number of the large estates, or manors, in Maryland, Virginia, and New York. At least one of those in Maryland dated back to the seventeenth century. The early parks seem to have been generally stocked with fallow deer brought from England. The Revolutionary struggle marked the destruction of nearly all the private deer preserves; but a few of them, especially in Maryland, continued in existence, and others were restocked after the end of the war. As few fallow deer were imported later, and it was generally believed that our native deer were unsuited for park purposes, private preserves did not become numerous. The common opinion as to native deer was expressed by the eminent authority on landscape gardening, A. J. Downing, who in 1852 wrote as follows:

All attempts to render our native deer really tame on home grounds have, so far as we know, failed among us, though with patience the thing may 
doubtless be done. It would be well worth while to import the finer breeds of English deer, which are thoroughly domesticated in their habits and the most beautiful objects for a park. ${ }^{a}$

When the above was written, both Virginia deer and American elk were doing well in a number of parks in the United States, and had been acclimatized in parks in England and on the Continent, where they were almost as tame and fully as hardy as the fallow deer. That these facts should have escaped the notice of Mr. Downing seems remarkable.

The American Turf Register and Sporting Magazine for April, 1831, contains a letter from W. E., of Roanoke, N. C., in which he gave interesting details concerning his herd of domesticated deer. These he claimed were so tame that his hounds readily distinguished their track from those of wild deer that occasionally visited the park. He wrote in part:

One-half of my park being a forest, the deer shelter themselves in it during bad weather, and they dislike cold so much that frequently they will not leare their shelter to come to the troughs, which are in an unprotected part of the inclosure. To prevent fights there should be at least one trough for erery two deer. I feed them on Indian meal, having found by experience that raw corn is apt to swell and kill them. One quart of meal per das is sufficient to keep a deer always fat. They are rery fond of sweet potatoes, which they will eat though half rotten; they like the leares but not the root of turnips.

Deer are very prolific. I have nerer owned but two does that had less than two fawus at a birth. A friend of mine owned a doe that had three fawns three years in succession and they were all females. ***

I have known but one doe to have fawns before she was 2 years old. *** $*$ They generally bring forth from the 1st to the 20th of June. The earliest that I have known was the 1Sth of May and the latest the 12th of July. Should a doe die leaving fawns, one of the other does attends to the fawns as well as if they were her own. Jnst before the time for them to hare roung, I put them up in six-sided pens made of rails. The fawns at first are quite wild. I do not hare them turned out of the pens before they are perfectly gentle.

The raising of deer for profit has seldom or never been undertaken in a systematic way in the United States. Breeders have stocked preserves with deer as game for private use or grown the animals in small inclosures for the pleasure of owning them. But the economic possibilities are now beginning to be apparent. Some who have abandoned the business for lack of proper range are yet convinced that it might be made profitable. From a mass of correspondence, the writer has selected the experiences which bear most upon economic results and upon the proper management of the animals in semidomestication.

${ }^{a}$ Rural Essays, p. 174, 1854. 


\section{EXPERIENCES OF BREEDERS.}

While hunting in the Adirondacks in 1874, Thomas Blagden, of Argyle, near Washington, D. C., captured a pair of fawns and took them to his home. In due time these deer bred and became the ancestors of several hundred head. In $1902 \mathrm{Mr}$. Blagden transferred 48 of his herd to his summer home at Saranac Inn, Upper Saranac Lake, in the Adirondacks. (Plate VII.) On account of insufficient range and food, both herds have been greatly reduced by sales, and the greater part of the Argyle herd has been destroyed by worthless dogs.

Mr. Blagden is confident that under proper conditions the business of raising deer may be made to pay well. In his own herd, by securing new bucks from time to time, he has carefully avoided continued inbreeding. His stock is vigorous and of the large size characteristic of the Adirondack and other northern deer. On this account they command an exceptionally high price, $\$ 50$ each for bucks and $\$ 75$ each for does. He feeds grain, using corm, and a mixture of bran and meal. During the summer as much wild food as possible is cut for the deer, which always care more for the rankest weeds than for the choicest grass. Of hays they prefer alfalfa to other kinds.

Mr. Blagden regards the water supply of a deer park as extremely important. Running water should be constantly accessible to the animals. He attributes the great winter mortality among wild deer in the Adirondacks entirely to the fact that all water courses are frozen solid, and to obtain water deer are forced to eat sleet-covered shrubbery, which, he thinks, poisons them.

W. R. McKeen, of Terre Haute, Ind., has a large herd of deer on his stock farm near that city. The Sportsmen's Review quoted an account of this herd from an Indianapolis newspaper stating that it is one of the largest, if not the largest, herd of near-domesticated deer in the State. The herd was started nearly twenty years ago with about half a dozen animals and with no idea of profit. With the exception of a few dairy cows, no other stock is now kept on the farm. The demand for deer is fairly active. Each fall a considerable number are sold, and shortiy before the Christmas holidays of 1906 between 30 and 40 were disposed of. The deer are sold to persons having parks of their own and to museums, menageries, and the like. There is also a demand each winter for venison. Altogether the sales keep the increase of the herd from overstocking the place. ${ }^{a}$

Writing March 28, 1908, John W. Griggs, of Goodell, Iowa, states that he has been engaged in raising deer about fourteen years. Until two years ago he sold his surplus stock for parks, but since then has 


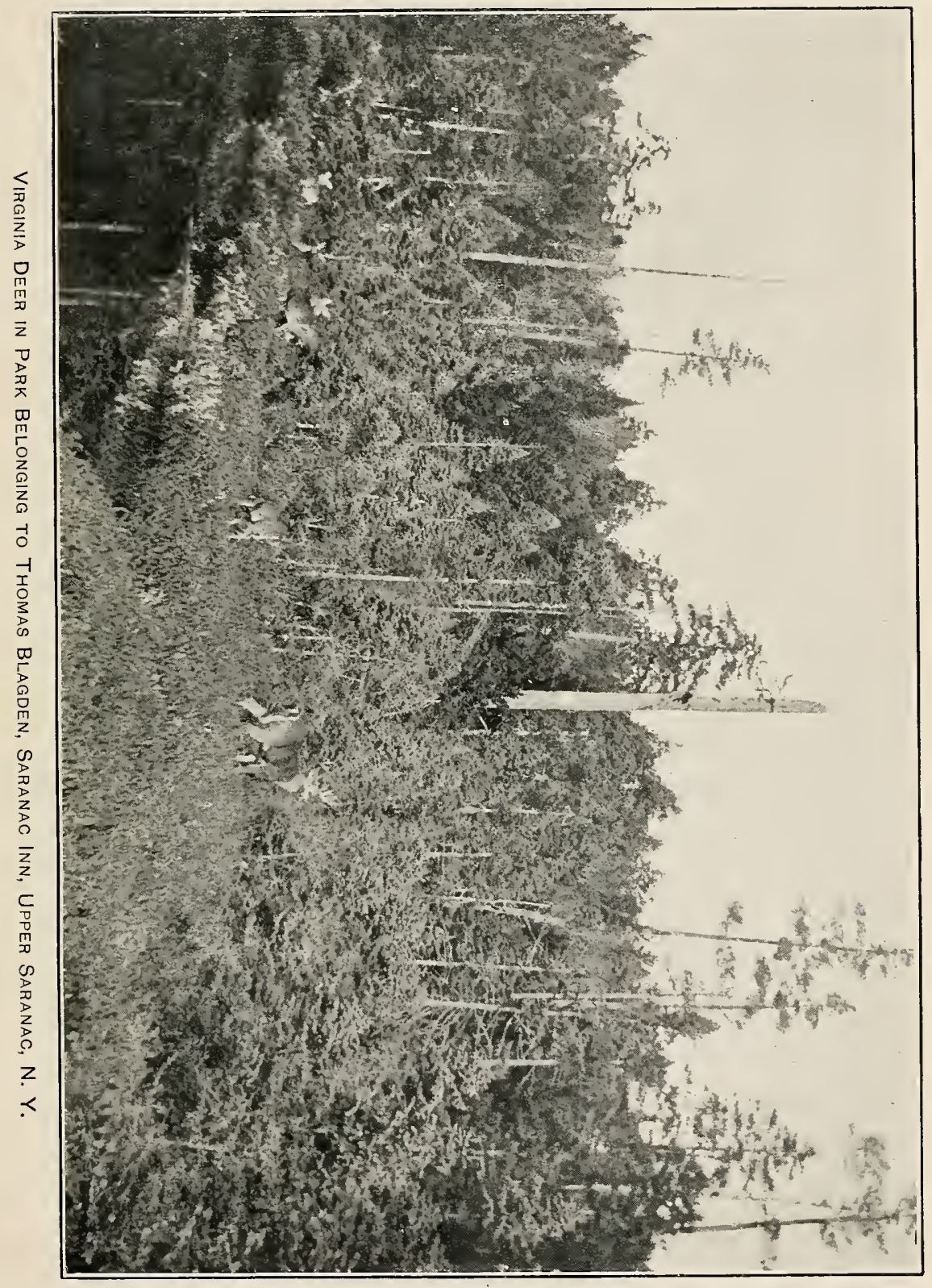



disposed of about half of it for venison. For park purposes he gets $\$ 20$ to $\$ 30$ a head; when fattened for venison they bring $\$ 20$ to $\$ 35$ a head. The animals do well in captivity. Mr. Griggs says further: "In raising a large herd the park should be divided into two or three lots, and one plowed each year and sown to red clover, mustard, rape, and seeds of different kinds of weeds. Blue grass and timothy are useless. Corn is the principal grain I feed. I feed it winter and summer. In winter I feed also clover hay, oat straw, and weedy wild hay. Deer when rightly handled are very prolific, and from 50 does one can count on 75 fawns. Deer can be raised profitably for venison-very profitably until overdone-but I would not advise one to go into it on a large scale without previous experience with deer."

Charles Goodnight, of Goodnight, Tex., writing March 26, 1908, states that he kept deer and elk on his plains pastures for a number of years, until he became convinced that his ranch was unsuited to browsing or partly browsing animals. He says: "With a properly selected place, the raising of these animals is not only practicable but very profitable. I should select a rough, broken piece of country with some prairie and glades, covered with as great a variety of shrubbery as possible. Deer will not eat ordinary grass if they can help it, but will eat wild rye and other kinds of soft grasses. With a properly selected place they are of very little expense after the pasture is fenced."

R. H. Harris, of Clarksville, Tex., on January 16, 1908, wrote that he had been engaged in raising Virginia deer for several years, and thinks that the business is admirably adapted for the profitable investment of capital. The Virginia deer is suited to almost every section of the United States. It is prolific, each doe usually producing twins. These grow very rapidly, and become the most beautiful, graceful, and healthy animals known. The demand for venison and deerskins is unlimited, the flesh being very high priced in city restaurants and cafés.

"No other meat," says Mr. Harris, "is equal to venison as a diet for the sick, it being easily digested and agreeing with the most delicate stomachs. Deer are easily tamed; the wildest fawn, if taken from the herd when young, will in a few hours become as gentle as a pet dog. I have for several years been raising them in large numbers. They run at will in woodlands and fields, are never handled, but fed occasionally, and are as gentle as a common herd of cattle. They are easily and cheaply raised and seldom, if ever, die from natural causes. After years of practical experience, I unhesitatingly state that the raising of deer is in profitableness second only to the raising of cattle.

"The cost of feeding deer averages about one-half cent each per day. They feed on all kinds of vegetables, buds, and leaves of trees, 
growing wheat, clover, peas, barley, oats, etc. Cotton seed is also a very cheap and satisfactory food for them. They eat also corn, bran, chops, fruit, and in fact anything that man or beast will eat, except dry hay. They live from twenty to twenty-five years. They are easily confined by a woven wire or barbed wire fence, $6 \frac{1}{2}$ feet in height."

\section{A DOMESTICATED HERD OF DEER.}

C. H. Roseberry, of Stella, Mo., writes under date of January 13, 1908, as follows:

My experience in breeding the common or Virginia deer covers a period of seventeen years, beginning in March, 1891, when as a boy of 16 I built a small inclosure of $1 \frac{1}{2}$ acres to confine a single doe that was captured as a fawn in the neighboring forest. A buck and other does were secured from year to year until in 1900 by purchase and natural increase my herd numbered 25 head of all ages.

From 1891 to 1901 I lost every year from disease an arerage of 20 per cent. The climax came in the drought year of 1901, when my loss was 50 per cent from the disease known as "black tongue." I am convinced that, as with cholera in swine, indiriduals recovering from this disease are immune from further attack. Apparently all of my herd were afllicted. The survivors and their progeny constitute my present breeding stock. I have made no purchases since 1901 , nor have I suffered any loss from disease.

For the last seren years my herd has areraged 70 per cent increase, all of which I have sold at satisfactory prices. I begau selling at $\$ 20$ per pair of fawns at 4 months of age and $\$ 30$ per pair of adults. I now get $\$ 40$ and $\$ 60$, respectively. I sell almost exclusively for pets and for propagating purposes, although a few surplus bucks have been sold for venison, averaging me 15 cents per pound gross weight.

If we except the goat, I know of no domestic animal common to the farm that requires so little feed and attention as the deer. My herd has a range of only 15 acres, two-thirds of which is set to white clover, blue grass, and orchard grass. I provide also a small plat of wheat or rye for winter pasture. With the above provision in this latitude no feed is required between April $\mathbf{1 5}$ and November 15. During the rest of the year a ration of corn, bran, or other mill feed, somewhat smaller than that required for sheep, in connection with a stack of clover or pea hay to which they bave free access, is sufficient to keep them in good condition. Deer eat with relish nearly all of the common coarse weeds, and for clearing land of brush they are, I think, second only to the common goat.

Probably the greatest expense connected with the business of raising deer is the fencing. Another item of trouble and expense when the animals are raised for pets, requiring that they be handled and shipped alive, is the fact that the fawus must be taken from the does when 10 days old and raised by hand on cow's milk. They are quite easily raised in this way, with but slight percentage of loss, but require frequent and careful attention for the first month. (Plate VIII.) When they are allowed to run with the does their natural wildness can not be overcome, no matter how gentle the does may be. (Plate III, fig. 1.)

I have found the business profitable on the lines indicated. I believe they could be profitably bred for venison alone, certainly with less trouble and expense, since the fawns would be reared by the does and the trouble and expense of raising by hand eliminated. 


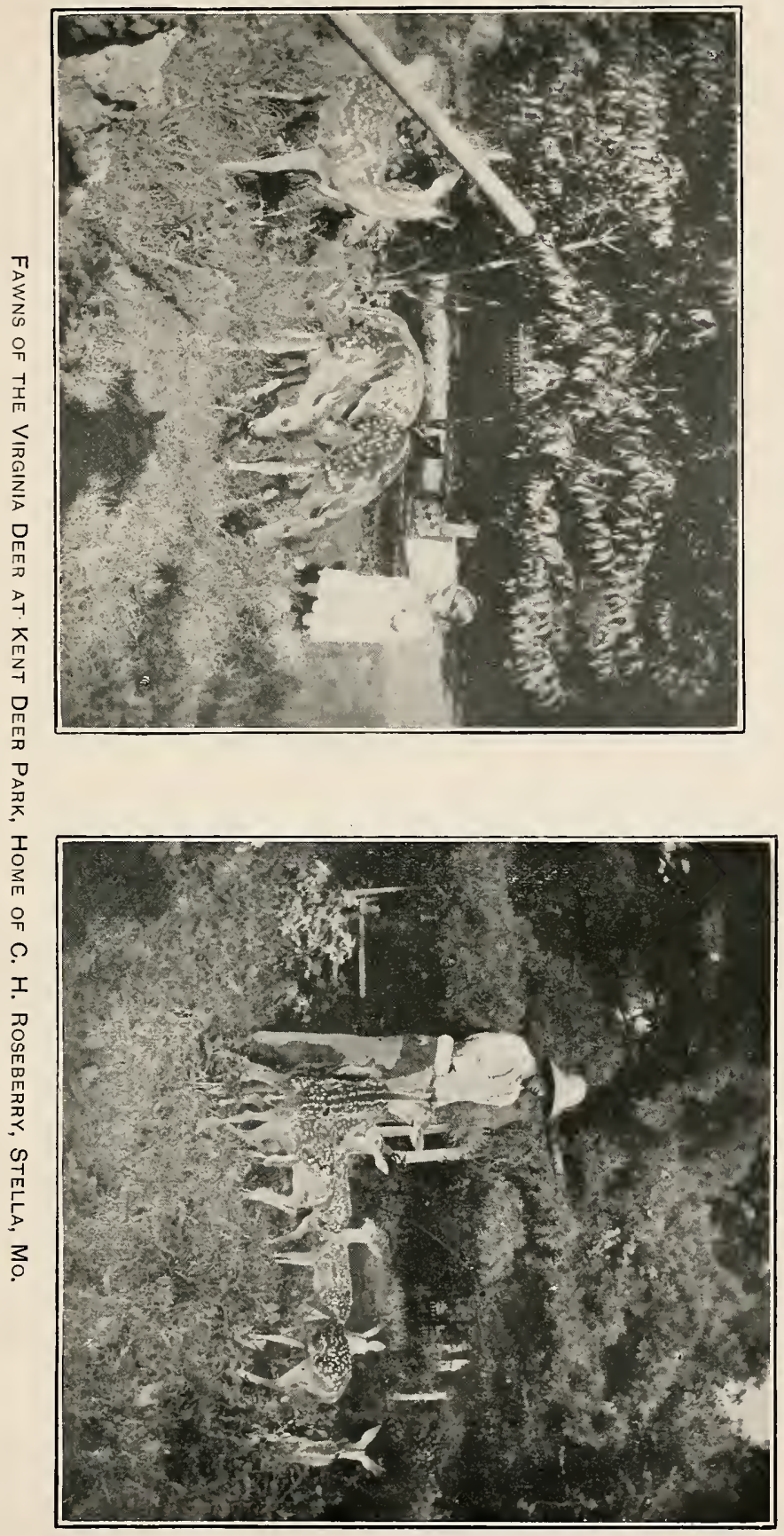



My experience does not coincide with that of some other breeder's in respect to the weakening of reproductive powers of deer by their confinement in parks. ${ }^{a}$ I have no barren does. Usually they produce a single fawn at 2 years of age; afterwards twins, and, in rare cases, triplets.

\section{INCREASE OF WHITE-TAILED DEER IN DOMIESTICATION.}

Early in 1900 a pet doe heary with fawn was delivered at the Taney County, Mo., game preserve belonging to the St. Louis Park and Agricultural Company. The doe had been thoroughly domesticated, and, refusing to join the wild deer in the preserve, remained near the home of the tenant and under the immediate care of his family. In the spring of 1900 she gave birth to two fawns, both does, which became as gentle as the mother. In the spring of 1901 the old doe again dropped 2 fawns. In 1902 there was an increase of 4 fawns, each of the young of 1900 having given birth to a fawn. By the spring of 1905 the domestic herd had increased to 25 deer, all the increase of 1 pet doe. ${ }^{b}$

A herd of mule deer at Crawfordsville, Ind., has increased with almost equal rapidity. These deer belong to James F. Boots, and are kept in a 4-acre inclosure. Mr. Boots writes that in 1899 he brought a buck fawn from Colorado, and nearly four years later he secured 2 adult does. From this stock he has had fawns as follows: 1904,$4 ; 1905,4 ; 1906,8 ; 1907,10 ; 1908,5 ; 1909,10$; from the 5 does then kept. All were raised except those born in 1908, the loss of which was attributed to excessive heat.

DEER HYBRIDS.

However undesirable hybrids among wild animals may be regarded by naturalists, the production of them among domesticated or semidomesticated species is of great economic importance. The experiments of breeders in hybridizing deer, aside from the apparent value of the results obtained, are highly interesting. Mention has already been made of hybrids between the American wapiti and the red deer as well as the Altai wapiti. The first of these crosses was obtained by the Prince of Pless, in Silesia, about a half century ago.

Judge Caton made experiments at Ottawa, Ill., and obtained a number of hybrids, the most important being those between the Virginia deer and the Acapulco deer (Odocoiteus toltecus) and between the Virginia deer and the Ceylon deer (Cervus axis). These deer exhibited no natural tendency to breed together, but when the male of the exotic species was absent or accidentally lost he introduced the buck of the Virginia deer.

${ }^{a}$ Cf. Catou, J. D., Antelope and Deer of North America, p. 304, 1877.

${ }^{b}$ Second Annual Report Missouri Game and Fish Warden, p. 20, 1907. 
John W. Griggs, of Goodell, Iowa, has succeeded in crossing the mule deer with several races of the whitetail. 'The hybrids were obtained by isolating the pairs in separate yards. As long as the different species or races are kept in a common pasture, each kind herds by itself and no sexual association between the different kinds takes place. Under such cireumstance or in the wild state crosses are exceedingly rare. Mr. Griggs obtained his hybrids by placing a buck of the mule deer with whitetail does before the rut began, and the offispring proved to be highly satisfactory as to size and stamina, and also were perfectly fertile. As was to be expected, however, offspring in the second generation of hybrids varied much in form, size, and other characteristics, and on the whole were not so satisfactory as the first generation. He thinks that his hybrids with the mule deer have stronger constitutions than the Virginia deer and are less liable to disease.

Charles Goodnight, of Goodnight, Tex., writes that he crossed the mule deer with the white-tailed deer with great success, making a valuable and beautiful animal with greater size and better meat than the common deer. The hybrids were fertile also, and Mr. Goodnight would have continued his experiments further, but, having no shrubbery or trees within his range, he found it unsuited to deer and liberated his herd.

\section{HABITS AND IMANAGEIIENT OF VIRGINIA DEER.}

Deer are polygamous like cattle. The rutting season is in November, the period of gestation is 205 to 212 days (about seven months), and the fawns are born in May or June. The young does breed usually when about seventeen months old, and have but one fawn the first time; afterwards they commonly have twins. The fawns are spotted, and remain so until the hair is shed in the fall.

The white-tailed deer is even more a browsing animal than the elk; and yet it can and often does manage to get along in summer on grass alone. In a cultivated pasture it eats rank weeds and wild grasses in preference to timothy or blue grass. Observation of deer feeding in a pasture several hundred feet away is insufficient to determine accurately what they are eating. A writer in The American Field states that he often saw mule deer apparently eating grass in the Colorado parks, and he had no doubt that they did so until a hunter informed him that they would not eat grass unless they could obtain no other food. Afterwards he had a number of times examined the stomachs of deer he had killed, and only once found what was unmistakably grass. ${ }^{a}$ 
The Biological Survey has examined a few stomachs of deer killed in the United States. A Columbia black-tailed deer taken in the Chemise Mountains, Mendocino County, Cal., had eaten acorns and an equal bulk of foliage, mostly willow leares. A young deer of the same species taken on Mount Shasta, California, had grass in its stomach. Three individuals of the Arizona race of white-tailed deer (Odocoileus virginianus couesi), taken at different times, had eaten, respectively, leaves of the little blue live oak (Quercus grisea), with some flowers and flower stems of Notina Tindheimeriana; green foliage, seeds, berries, and the pods, beans, and leaves of Acacia sp.; and green leaves of Thermopsis montana, vetch, strawberry, geranium, Senecio (two species), aspen, and a flat green lichen-no trace of grass or acorns. A white-tailed deer killed in Minnesota in April had nothing but lichens in its stomach.

In captivity deer eat almost erery kind of vegetation, including ail sorts of garden stuff. They are fond of acorns, beechnuts, chestnuts, and other mast. Lily pads, fallen leaves, lichens, and mosses are freely eaten; so that, with plenty of range and an abundant variety of plants, there is little difficulty about food for deer. A good supply of running water must be provided, and the animals should hare access to rock salt. If the browse and pasture are scant, some grain should be fed even in summer, and it is best to feed regularly in winter. Of the grains, corn is generally recommended; there is no waste in feeding it, as deer pick up every grain. Coarse hay full of weeds is preferable to timothy or other tame hays, except alfalfa. Of clover hay, deer usually pick out the dry flower heads greedily, but waste the other parts. In the northern half of the United States winter shelter should be provided for deer.

The practice of pasturing hogs in deer parks is objectionable, since they destroy nearly all the mast. For this reason the wild boar is unsuited for American game preserves intended for deer and wild turkeys.

\section{TICIOUS BUCKS.}

The dangerous character of some deer, especially the males, in semidomestication has already been discussed. The whitetail is no exception. Charles C. Worthington, writing to the Biological Survey of his experience with ricious bucks, says:

The first serious difficulty I experienced, and one the gravity of which should not be lost sight of by anyone starting a preserve, was with the tame bucks at the rutting season. These bucks from being tame and docile would become at this season fierce and dangerous. They would attack anyone at sight, eren a person on horseback or in a wagon. Some of the gamekeepers had narrow escapes from being killed; in one or two instances being seriously injured. A pedestrian's only chance for escape was to climb a tree. Those bucks which developed this ferocity had to be systematically hunted and shot on sight. 
Those left were the ones that had not been originally tamed, and not being accustomed to the sight of man, had not courage enongh to make an attack. My experience is that a wild buck, even in the rutting season, still retains his nat ural fear of man, and, except when wounded, is never dangerous.

Instances of fatalities from attacks of vicious bucks of the Virginia. deer are not lacking. A rather recent one was the death of Herbert Bradley at Montclair, N. J., November 10, 1906. While working alone on his grounds, he was attacked by a pet deer and so badly wounded that he bled to death before aid could be obtained.

The remarks about castrating the elk apply as well to the common deer. A number of vigorous bucks, however, must form a part of any considerable herd, for a single buck can serve only a limited number of does. One buck for each ten or twelve does will probably be enough. New bucks should frequently be introduced to avoid inbreeding.

\section{CAPTURING LIVE DEER FOR SHIPAIENT.}

In 1887 C. W. Marsh, of De Kalb, Ill., in a letter to The American Field, said:

Thirteen years ago this spring I fenced in a few acres of natural woodland with a bit of prairie adjoining my residence lot for deer; the fence was $8 \frac{1}{2}$ feet high and proportionately strong. I advertised for deer, and during the season got a buck from Sionx City, caught in Dakota; a doe from Kansas; another from Missouri; and still another from a gentleman in De Kalb, this last having been sent to him when a fawn from Arkansas. They were all red or Virginia deer, but showed considerable difference in size, form, and disposition; and they were all tame; that is, had been pets and would bear handling; hence had come quietly and unharmed in their cages. These began breeding at once, the does dropping two fawns generally. The young deer were as wild probably as any in the forest at first, but as the does were tame they also soon became quite tame, though not one has ever submitted to handling. They were rugged, hearty fellows, and in course of a few years I had a herd of over twenty. Occasionally I killed one for venison, and as they increased so fast I caught and gave a number to friends and sold a few. While the old does lived the young were easily caught, as the former would go into any cage or trap for food during the winter months and the latter would follow, and although they would struggle fiercely when canght, they gave up and quieted down as soon as hands were removed. None were lost in shipping. In due time the old does died, and all of my present herd except one buck were dropped by does that were bred in the park. Apparently each succeeding generation became wilder and more difficult to catch, and I have for some few years past thinned them out in the fall by shooting and marketing them. Still, they always answer my whistle and come around me for food. ***

They are hardy, active, and very shy of anything strange, but manifest strong attachment for home. Several times during these many years dogs have gotten into the park and run some of them out. When scared thus, nothing will stop them, and they will either go through or over any fence-they have frequently bounded over mine, $8 \frac{1}{2}$ feet high-but when out they will usually jump back again of their own volition, even though they had been off in the woods or about the park outside for weeks. In such instances they hung 
around for a time seeking an easy entrance apparently (it is useless to try to drive them in), and failing in that they finally jumped over or smashed through the fence. When out they are very wild, but when they get in will come up for feed and be as tame and unconcerned as before.

As a culmination to the increasing wildness of his herd, Mr. Marsh found that in capturing and crating deer which he sold for stocking purposes he lost a large per cent as a result of exhaustion from their struggles. $^{a} \mathrm{Mr}$. Blagden relates a like experience in shipping live deer to purchasers, but later he overcame the difficulty by an ingenious trapping device. Charles $\mathrm{C}$. Worthington uses a similar trap at his IVarren County (N. J.) preserve.

In a recent letter to the Biological Survey, Mr. Worthington describes his deer trap as follows:

As a demand exists for deer to be used for the restocking of state lands and for establishing private preselves, I, several years ago, began experiments in trapping them. It was well known that a wild deer caught in any small inclosure of wire will kill himself in his efforts to escape, but believing that he would not do this if the fence were made in such a way as to prevent his seeing through it, $\mathrm{I}$ constructed an oblong trap, about 20 feet wide and 30 feet deep, of boards 10 feet high, nailed closely together, so that nothing could be seen through them. A board door of the same height and running loosely in vertical grooves was fitted to one end, and opposite to it a narrow board passageway was built just high enough for a deer to enter and about 5 feet long; at the onter extremity of this passageway was placed a similar sliding door, big enough to close tightly the end of the passage. The main door is held open by a wire that extends several hundred feet to a blind, where the trapper stands concealed. When the snows are on the ground, this trap is baited with tempting food, which the deer finally enter the trap to secure. When it is found that they enter the trap without hesitation, a man stations himself on watch, and at such time as a number of deer are inside, drops the sliding door and imprisons them. They are left for a few hours until their first fright is somewhat allayed. Then crates, just large enough to hold one deer, and having only enough openings to supply sufficient ventilation, are placed, one at a time, in front of the smaller sliding door at the end of the passage. The crates are provided with a corresponding door. These being raised, the deer are made to enter the crates one at a time, and so are secured. The men, during this entire operation, remain concealed.

This form of trap has proved effective and satisfactory in erery way. There have been caught in it during the last few years ovel 300 deer, which have been transferred to various localities throughout the country with a death rate of less than 4 per cent. The trapping operations hare to be discontinued by the mildle of February, owing to the does being then so heary with fawn that any attempt to crate and transfer them is attended with too much risk.

The game commissioners of Pennsylvania and New Jersey have purchased numbers of these deer to be liberated in various parts of their respectire States. The experiment of restocking districts from which these animals disappeared long ago has proven most successful and popular. 


\section{WILD DEER IN PRIVATE PRESERVES.}

In many parts of the United States private preserves have been established by either individuals or associations and stocked with deer and other big game. Such enterprises have met opposition from both citizens and sportsmen, the latter being frequently ousted from favorite hunting grounds by the fencing and posting of such preserves. The feeling against large deer parks in America is in part a survival of an Old World prejudice against them, but in the main results from doubt of the wisdom of permitting large holdings of unproductive land. In a majority of the States private preserves are still subject to all the game laws of the State, so far as time and manner of hunting in them are concerned, and thus the owners are unable to reap the full economic advantage of their possession. While these conditions prevail, large game preserves are open to the objection that they are sources of wealth which are not fully utilized.

A few private preserves have been stocked with exotic game-red deer, wild boars, and the like-and in many of them large expenditures have been necessary to provide good sport. In some of the States the rights of owners of such preserves to the unrestricted use of the game within them is not clear, while such rights are clearly set forth or denied in the laws of others. As long as game within the preserve is comparatively scarce, owners will be content to use it in strict conformity to the hunting laws of the State. But when the game increases so as to overstock the preserve, or to become a source of revenue to the promoters, greater privileges will be demanded and will have to be granted, for grades of domesticity in deer and elk are not sharply drawn, and there is no difference, so far as ownership is concerned, between those raised in parks for venison and those produced in a fenced preserve for sport.

Full recognition of private ownership in game does not interfere with the right of the State so to regulate its disposal as not to jeopardize the preservation of wild game. Game regulations must be insisted upon, and the owners of private preserves will usually be as vigilant as anyone in helping to enforce them.

The increase of white-tailed deer, when protected within suitable large fenced preserves, is remarkably rapid, and there is no doubt as to success in propagating them under natural conditions as wild game. The experience of a large number of hunting clubs and individuals that have stocked preserves is favorable. In the ten years between 1892 and 1902 deer in Buckland Park, the Warren County, N. J., preserve belonging to Charles C. Worthington, increased from 19 to about 400 head, a number considered too large for the sustaining capacity of the park. The St. Louis Park and Agricultural Company have about 1,000 deer and 400 elk on their large preserve in Taney County, Mo. About six years ago the Otzinachson Rod and 
Gun Club, of Clinton County, Pa., placed about 90 deer, mostly does, in their 4,000-acre park. These have multiplied to nearly 2,000 head, and a further increase of about 1,000 fawns was expected during the season of 1908. These experiences in stocking large preserves with deer, although highly successful, are probably not exceptional.

\section{EFFECT ON GAME SUPPLY.}

The effect of private preserves on the supply of game in the State should not be overlooked. While they may temporarily restrict the hunting privileges of a few citizens, ultimately they become a source of game supply secondary in importance only to state preserves. Already a number of private preserves have become overstocked, and game has escaped or been turned out to become the property of the people. Both deer and elk are said to have escaped from the Corbin preserve in New Hampshire and from the Whitney preserve in Massachusetts. The game in the well-stocked preserve of Dr. W. S. Webb in the Adirondacks became the property of the State when, in 1903 , the owner demolished the fences which for many years had surrounded his 8,000-acre park.

Charles C. Worthington writes, May 21, 1908, that when, in 1902, the deer in his New Jersey preserve became too numerous to be supported by the acreage inclosed, several wide gates were left open for a few months. Few of the animals availed themselves of the opportunity to escape. Mr. Worthington says: "There was little incentive for them to leave the inclosure, and most of those that did probably returned at the first alarm, their instinct directing them to the inclosure as a protected, safe retreat. The few that remained outside have increased in numbers, until now the region round about for a radius of several miles is well stocked. While some complaint has been made by the farmers in the neighborhood that the deer destroy some of their grain, the general sentiment is in favor of having the laws for their protection rigidly enforced."

The success of private enterprise in propagating deer in inclosures is an object lesson for state game commissions and others, and suggests that the State should undertake similar work for the public. The establishment of game preserves on public lands of the State is a most important step in game preservation, especially if the lands are already stocked with wild deer. But the further introduction of breeding animals will hasten multiplication, until the preserve becomes a source of game supply for the surrounding territory. While more national preserves are needed, a system of state preserves is allimportant. Those already established in Pennsylvania and other States have proved highly useful, and it may truthfully be said that in every country that has tried them, public game preserves have been instrumental in increasing the game supply. 


\section{GAME PROPAGATION AND GAME LAWS.}

The chief obstacle to profitable game propagation in the United States lies in the restrictive character of state laws affecting the killing, sale, and transportation of game. Many of the States, following precedent, lay down the broad rule that all the game in the State, whether resident or migratory, is the property of the State. A few of them, notably Nebraska, North Dakota, and Tennessee, except such game animals as are "under private ownership legally acquired." A few others encourage private ownership by providing means by which wild animals may be captured for domestication. Generally, where private ownership of game is recognized by law, the right to kill such game is granted, but the owner is hampered by the same regulations as to season, sale, and shipment that apply to wild game. One by one, however, state legislatures are coming to recognize the interests of game propagators and to modify the game laws to meet the changed view.

\section{TRANSPORTATION OF LIVE DEER.}

Except in a few States that provide for the capture of wild deer under permits, the only source of stock for private preserves is the animals already in captivity. Hitherto the shipment of live deer and elk from private preserves has often been permitted because game wardens and others interested could see no advantage from interfering, notwithstanding that a literal construction of the law in many States would absolutely forbid such shipments. Pennsylvania is one of the few States that give owners of private deer preserves the positive right to sell and ship deer or fawns at any time for propagating purposes.

\section{TRANSPORTATION OF VENISON.}

Under the license system and within specified limitations, some of the States permit the holder of a hunting license to ship venison lawfully killed to his home within or without the State. The general transportation of venison, as well as its export out of the State in which it was killed, is usually forbidden. Only a few States permit the export of deer, and two of them-Delaware and Ohiohave no deer, so that the animals are not mentioned in recent game laws of those States. The laws forbidding export usually specify deer or parts of the carcasses of deer; so that the legal shipment of live deer is impossible except in States which make prozision for their export for propagating purposes.

Before 1909 the two sections in the game law of New York referring to the killing and sale of deer specified "wild deer," but in the section relating to transportation the word "deer" was unqualified. The manner in which this omission at first affected the owner of a 
private preserve is illustrated by the decision rendered in 1907 in the case of Dieterich $v$. Fargo. ${ }^{a}$

The American Express Company refused to receive and transport deer raised and killed in a private preserve in Dutchess County. The owner of the herd, Charles F. Dieterich, found it necessary to kill some of the bucks each year and ship them to New York for sale. On the refusal of the express company to transport his venison, he applied for a temporary injunction against its president, James C. Fargo, claiming that the law prohibiting transportation did not apply to domesticated deer. The supreme court of New York County, in December, 1906, decided in favor of Dieterich. This decision was reversed by the appellate division of the supreme court of the State, May 10,1907, by a majority of the court. The opinion by Justice O'Gorman was to the effect that the section of the law prohibiting the transportation of deer from one county to another, and requiring express companies to refuse to accept deer when not accompanied by the owner, applied to domesticated as well as to wild deer. The transportation of deer raised on a private preserve was held to be subordinate to the police power of the State. One of the dissenting opinions held that Dieterich had the same natural and legal right to fence his farm and devote it to the propagation of deer that he had to use it for raising cattle or sheep.

To market his deer in $1908 \mathrm{Mr}$. Dieterich resorted to the novel expedient of paying transportation for a number of men in the city of New York to go to his country preserve, each shoot a deer and accompany the carcass to market, as required by the law. However, the New York court of appeals finally, February 23, 1909, reversed the decision of the lower court and held-one of the six judges dissenting - that the law concerning transportation of venison did not apply to that from domesticated deer bred in confinement, and that the owner of such deer was not restricted as to the number he may kill and ship during the open season. The law regulating transportation of venison has recently been amended to provide for shipment from private preserves.

As would be expected by those familiar with the history of British deer preserves, the laws of the various Canadian Provinces are in general more liberal toward the owners of private deer parks. The general tariff law of Canada permits the export of any home-bred deer under regulations made by the Governor General in Council.

\section{KILLING DEER RAISED IN PRIVATE PARKS.}

The failure to except deer kept in private preserves from the operation of the laws providing a close season for wild deer prevents the owner of deer from using the venison for food in his own family. 
He is restricted to a very short open season at a time when, on account of the rut, the animals are least desirable for food. If permitted to sell the venison, even in his own State or county, he must do it during the same limited period, when, owing to the presence of wild game in the market, he may be compelled to accept an extremely low price. To make the business of growing venison profitable, the grower must be able to choose his own time for marketing the product, as in case of beef or pork.

\section{SALE OF VENISON.}

In more than half the States and Territories the sale of renison from private preserves is illegal at all times, and until recently the sale was illegal in nearly all the States. Several States now forbid the sale of venison produced within them, but permit the sale of that imported from other States, a most unjust discrimination against home industry.

A recent experience in Pottawattamie County, Iowa, illustrates how the law sometimes affects private ownership of deer. The facts are gathered from newspapers, but in the main have been verified by correspondence. J. Cuppy, of Aroca, owned a herd of 20 deer, but died a few years ago without direct heirs and without having made provision for the deer, which had escaped from their inclosure. The administrators could not catch the animals nor lawfully kill them. The herd has increased to nearly 200 head of partly wild deer. They forage on the farms and gardens of the neighborhood, doing some damage, especially to stacks of alfalfa and corn shocks. No one may legally kill them, and prosecutions promptly followed when the county officials learned that a few of them had been shot and converted into venison.

The decision in the case of the State of Missouri $v$. Weber (102 S. W., 955) further illustrates the tendency of courts to give a literal interpretation to laws in order to uphold police regulations concerning game. Eight deer, from which the evidences of sex had been removed, were exposed for sale in the Kansas City market. They had been raised on a stock farm in Henry County, and came from a tame herd which had been in possession of the owner for twenty-five years. They were kept with cattle in a pasture surrounded by a high fence. The animals were never hunted, but the owner had been accustomed to kill several of them every year for sale in the Kansas City market. Defendant Weber was arrested and tried in the Jackson County criminal court in December, 1906. The defense was that the law did not refer to tame but to wild deer. The defendant was found guilty, and appealed his case. It was transferred from the court of appeals to the supreme court, which in its decision upheld the lower court. The court held that the law applied 
to tame deer well as wild, and further that the act did not violate the constitutional prohibition of taking private property for public uses without compensation.

George S. Good, of Lock Haven, Pa., wrote in April, 1908, that deer had multiplied so rapidly in the preserve belonging to the Otzinachson Rod and Gun Chub that the annual increase would soon reach about 1,000 animals. He thought the time not far distant when the club would be compelled to market or dispose of 1,000 deer each year to prevent overstocking the preserve. But at that time the law of the State did not permit the club to sell these animals except to stock other preserves; neither could they be killed except in strict conformity with the laws of the State concerning wild deer. Each of the 14 members of the club or guests of the club could take one deer in the open season.

If the surplus animals from large preserves like that just mentioned could be turned into venison and sold judicionsly, they would become a source of steady revenue. A thousand adult deer marketed when the time is favorable should yield a gross income of nearly $\$ 25,000$ a year. The Pennsylvania legislature of 1909 passed a law providing a means by which venison from private parks may be sold in the open season.

Attorney-General Atkinson, of Washington, in 1906, delivered an opinion concerning game raised in captivity, part of which is of interest in this connection:

It is a well-known principle of law in States generally that wild birds or animals which have been kept in captivity and have become more or less domesticated, when reclaimed by the art and power of man, are the subject of qualified property, and are, as a general rule, under the protection of the law the same as any other property, and are at the disposal of the owner for using or selling as he desires. This seems to have been the law for thousands of years in civilized countries, and it would seem to have been the sensible principle to follow; for without doubt all animals and birds were once wild in feræ naturæ state, and by the application of this principle all people have tamed and acquired domesticity in animals and fowls from the game state, from elephants and horses and cattle down to chickens and canary birds.

It is my opinion that our laws in this State covering the subject were intended by the legislatures to relate strictly to game, meaning animals and birds in their wild, free, roving state, and these statutes were not intended in any manner to limit or prevent any probable or possible occupation or industrial development relating to the growing and raising and domesticating of any kinds of birds or animals for food products and the general use of the people.

\section{STATE LAWS THAT RECOGNIZE PRIVATE OWNERSHIP OF DEER.}

Recognition of the rights of private ownership in deer and other big game is now given in laws of the States named below. It will be observed that most of the provisions were enacted recently.

Arkansas._- Nothing in this act shall be so construed as to prevent any person or persons from having in their possession or buying 
or selling or shipping or any railroad from receiving for transportation any deer or fawn when such deer or fawn is raised in captivity for domestic purposes and is accompanied by an affidavit from the raiser to this state of facts." (Acts of 1907, No. 43.)

Colorado.-No one may maintain a private fish or game preserve for profit without taking out a license to do so. Owners of licensed private preserves are permitted to sell and ship deer or other quadrupeds, if the carcasses or live animals are accompanied by proper invoice and a permit from the state game and fish commissioner. A fee is charged for the license and for each animal shipped by permit. (Laws of 1899, ch. 98.)

Florida.-An act passed in 1909 protects private preserves from trespass. Such preserves are limited to 640 acres, and must be carefully posted. The game in them may not be killed for three years, and thereafter only in compliance with the general hunting laws of the State. (Ch. 5940.)

Illinois._. "Provided, that any person who breeds and raises deer for market, where the same has been bred and raised within an inclosure, may kill and sell the same from October 1 to February 1." (Laws of 1909, p. 236.)

Indiana.-The section against killing and possession of game has this clause: "Provided, that the provisions of this section shall not apply to any person or persons owning or having under his domain or control any deer, buck, doe, or fawn bred or raised in any deer park." This would permit sale of venison, but probably not its export. (Laws of 1907, ch. 219.)

Iowa.-The statutes declare it unlawful for any person other than the owner or person authorized by the owner to kill, maim, trap, or in any way injure or capture any deer, elk, or goat, except when distrained as provided by law. As Iowa has no wild deer except the few that have escaped from a private herd, the sale of venison from private preserves is not prohibited.

Kentucky.-The state law especially protects game in parks from poaching and trespass. (Stats., sec. 1250.)

Maine.-The game and fish commissioners are authorized by law to grant permits to capture moose, caribou, deer, and birds for park purposes within the State. This does not permit the sale of such game. (Rev. Stat. 1903, ch. 32, sec. 40.)

Massachusetts. - The owner may at any time kill or sell his own tame deer kept on his own grounds. (Acts of 1907, ch. 307.)

Michigan.-An act passed in 1909 makes it unlawful to capture or destroy deer kept within or that have escaped from any private inclosure. (No. 167.)

Minnesota.-Persons who desire to domesticate deer, moose, elk, or caribon may secure a permit to do so from the state board of game 
and fish commissioners by paying a fee of 50 cents for each animal in captivity and a like fee for each animal added later by natural increase or otherwise. The animals kept in captivity may be sold or shipped within or without the State by written permission from the commission. (Laws of 1899, ch. 161.)

Nissouri._" Nothing in this act shall be construed to prevent the shipment of deer or elk, alive or dead, from private preserves, when such elk or deer are raised in captivity." (Laws of 1909, p. 536.)

New Hampshire.-The Blue. Mountain Forest Association may kill elk, deer, and moose within the confines of its game preserve until January 15 of each year and transport them outside the State at any time when accompanied by a certificate from the fish and game commission. (Pub. Stat. 1901, ch. 131, sec. 6.)

New York.-Deer may be sold during the open season, and moose, elks, caribou, and antelope from private parks may be sold during the same period. Common carriers may transport animals into the State for breeding purposes. The section forbidding transportation of venison was recently (1909) amended to provide that it "shall not apply to domesticated deer propagated in wholly inclosed deer parks. when shipments made from such parks are accompanied by a permit issued by the forest, fish, and game commission under conditions prescribed by the commissioner." (Ch. 474.)

North Carolina.-Twenty-two counties permit the owner and keeper of an inclosed game reserve, who raises deer for use or sale, to kill, sell, or use those raised or kept in said inclosure. These laws were passed in 1907 and 1909.

North Dakota.-The state game and fish board of control is authorized to issue permits to breed or domesticate any of the game birds or animals mentioned in the law. An annual report is required from persons holding such permits, and they may sell or ship game within or without the State upon receipt of written permission to do so from the board. (Laws of 1909, ch. 128.)

Olitahoma.-A section of the law passed in 1909 permits the sale of domesticated game animals and birds within the State. The law is silent on the subject of their export. (Ch. 19.)

Pennsylvania.-The state board of game commissioners may issue propagating certificates to individuals or associations that desire to raise deer or other large game animals. The land shall be inclosed by an approved wire fence not less than 8 feet high. All wild deer must first be driven from the land under the direction of a representative of the state board. A careful account of all game raised or brought to the preserve must be kept and reports of any increase made annually to the board. Deer may be killed inside the preserve and shipped only during the open season and for thirty days thereafter. They may be shipped alive for propagating purposes at any 
time. Each deer or carcass of deer shipped from the preserve must bear a tag furnished by the state board, by which it may be identified at any time. (Acts of 1909, No. 204.)

South Dakota.-The state game warden may issue permits to breed or domesticate deer. moose, elk, caribou, buffalo, or game birds. Annual reports are required from holders of permits. On receipt of written permission from the game warden, any of the animals held in possession in private preserves may be sold or shipped within or without the State. (Laws of 1909, ch. 240.)

Vermont.-A person may kill, sell, or dispose of deer which were abtained without the State and are owned and confined by him in a park or inclosure. (Pub. Stat. 1906, sec. 5326.)

Wisconsin.-The fish and game warden may issue permits to breed or domesticate deer, moose, elk, or caribou. A system of marking the animals in preserves established under the permits is authorized, and such animals may be sold or shipped within or without the State upon receipt of written permission to do so from the state game and fish warden. A tag identifying the animal by number must accompany every carcass or part of the carcass shipped or exposed for sale. (Laws of 1909, ch. 525.)

A few other States except from the declaration of state ownership of game that which is " under private ownership legally acquired." In the absence of specific laws permitting the sale and export of such game, there is uncertainty as to how courts would decide concerning the rights of game propagators in these States.

\section{RESOLUTIONS BY THE AMERICAN BREEDERS' ASSOCIATION.}

At the annual meeting of the American Breeders' Association held in Washington, D. C., January 28-30, 1908, the subject of breeding game and fur mammals had an important place on the programme, and at the close of the sessions, January 30, the following preamble and resolution were adopted:

Whereas there are vast possibilities in our wild meat, fur, and game mammals, and birds, as a basis for stocking our private and public forest reserves and game preserves with a view to the conservation and fuller ntilization of our natural resources and as a source of blood to be used in forming hybrids with domestic animals; therefore,

Resolved, That the American Breeders' Association urge the attention of Congress, of state legislatures, sportsmen's societies, and private parties to the preservation of the American bison, the various members of the deer family, mountain sheep, arctic foxes, grouse, pheasants, quail, and other mammals and birds, and the carrying out of experiments to determine their wide use on lands not suited to domestic species and the determination of their vaJue in the foundation of hybrid animals designed for prodnction under wild and semidomesticated conditious. 
At the annual meeting of the same association held at Columbia. Mo., January 6-8, 1909, the following resolution was adopted:

Resolved, That state laws regulating shooting, possession, and handling of game should be amended so as to permit the sale of live game for propagation at all times. That hand-reared game and game reared in a wild state by breeders (including farmers) should be distinguished by law so that such preserved game can be sold legally uncier state regulations, except during the breeding season.

\section{SUMMARY.}

The foregoing information relating to the raising of deer, elk, and other large game animals in confinement may be briefly summarized in the following conclusions:

The rearing of wild game mammals, both native and introduced, offers a promising field for experiment, as well as for the practical investment of capital.

The Rocky Mountain elk and the Virginia deer can be reared successfully and cheaply under different conditions in regard to food and climate, as has been proved by many successful experiments. The complete domestication of either species is a possibility which, if realized, would be a source of lasting benefit to the world. With proper encouragement, the production of venison from both elk and deer can be made profitable industries on lands unsuited for cattle, horses, or sheep. The rearing of both species for stocking parks and game preserves would for a time be even more profitable than the production of venison.

Instead of hampering breeders by restrictions, state laws should be modified so as to encourage the raising of deer as a source of wealth to the individual and the State. Safeguards against the destruction and sale of wild deer for domesticated deer are necessary. For this purpose a system of licensing private parks or of inspecting and tagging or otherwise marking live animals or carcasses sold or shipped is recommended.

It is believed that with proper encouragement much of the otherwise waste land in the United States may be made to yield profitable returns from the production of venison, and that this excellent and nutritious meat, instead of being denied to 99 per cent of the population of the country, may become as common and as cheap in our markets as mutton. 



\section{IN DEX.}

Page.

Acclimatization of the eland . of the nilgai.

\#sthetic reason for domesticating animals.

Agriculture and transportation, mammals for .

Alces americana.

gigas.

American Breeders' Association............. resolutions, $1908 \ldots \ldots \ldots \ldots \ldots . . . . . . .$. resolutions, 1909.

American Institute......................

American antelope....................... protection.......................... range..............................

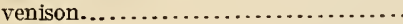

Antelopes, exotic. smaller.

Antilocapra americana

Antlers. of Altai wapiti. uses.

Arkansas, deer raised in captivity........... Atkinson, Attorney-General, of Washington. Audubon and Bachman on domestication of elk.

Axis deer.

Baird, S. F........................ 11, 16, 18, 29 Bedford, Duke of, parks belonging to.. 13,14,22, 23

Binney, Henry, fence for elk............. 37

Blagden, Thomas, experience with deer ... 40,42, 49

Blaubok, extermination.................. 9

Blue Mountain Forest Association......... 57

Blue Mountain Park................. 19, 28,57

Bonine, Isaac, experience with elk.......... $\quad 32$

Boots, James F., experience with mule deer.. $\quad 45$

Boselaphus tragocamelus................. 13

Bradley, Herbert, killed by deer............ 48

Buckland Park, New Jersey.............. 50

Buffalo, extermination ................... 27

Bull, H. C., killed by elk................. 38

Canada, export of park deer.............. 53

Caribou, barren-ground.................. 16 woodland........................... 16

Carroll, W. J........................... 17

Caton, J. D.................... 12,31,38,39,45

Cephalophus.......................... 14

Cervulus muntjac...................... 24

Cervus asiaticus...................... 21 axis ............................... 23,45 canadensis....................... 19,25 unicolor........ 23

Chinese water deer.................... 24

Chital................................. 23

Colorado, private parks................... 56

Corbin preserve (Blue Mountain Park)... 19, 28,57

Cuppy herd of deer in Iowa................

Danger of introducing foreign animals....... 24

Deer, Acapulco........................ 45

Columbia black-tailed .............. $\quad 21$ crating for shipment................. 48 exotlc.
Page.

Deer, fallow ............................ 21

family, importance................ 14

food.............................. 47

hair............................ 15

mule........................... 20

North American.................. 16

park at Roanoke, N. C............. 41

parks, early...................... 40

effect on game supply ......... 51

Père David...................... 23

red.............................. 21

small......................... 24

Virginia......................... 20,40

white-tailed..................... 20,40

management...................... 46

Deerhorn, uses.......................... 15

Deerskins........................... 15

Dieterich, Charles F., experience with deer.. 53

v. Fargo, case of ................. 53

Domestication of antelope............... 12

caribou......................... 16

elk........................... 20,29

mammals....................... 8 æsthetic reason for.............. 9

for use in agriculture and transportation ................... 10

for food ..................... 10

for fur..................... 10

selection of species............. 10

moose........................... 18

white-tailed deer.................... 20,40

Downing, A. J., on native deer for parks..... $\quad 40$

Duikers.............................. 14

Eland .................................. 13

Elaphuras davidianus................. $\quad 23$

Elk................................ 19,25

castration ......................... 39

clearing out underbrush............. 35 cost............................ $\quad 37$

enmity toward wolves and dogs...... $\quad 39$

fence........................... 34,37

flesh........................... 26

food $\ldots \ldots \ldots \ldots \ldots \ldots \ldots \ldots \ldots \ldots \ldots, \quad 37$

gestation........................ 26

habits ........................... 25

hybrids.............................. 28

in $A$ dirondacks.................. $\quad 28$

in eastern United States............. 27

in Ozark Mountains.................. 33

management..................... 36

parks........................... $\quad 36$

preservation....................... $\quad 26$

range.......................... 19

Rocky Mountain.................. 19,25

round-horned...................... 19,25

venison........................... 26

vicious male .................... 38

weight............................. 34

Wyoming herds ................... 25

Exotic specles, introduction of............ 24

Fence for deer............................ 44 
Page.

Fence for elk

Florida, law protecting private parks .....

Food of deer.

of elk.

Foreign animals, objections to introduction of

Fur, rearing mammals for

Game in Maine.

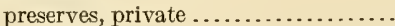
state.

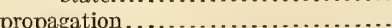

Gazelles.

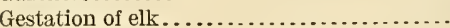

muntjaes.........................

white-tailed deer

Gilbert, J. W., experience with elk........

Good, Geo. S., quoted...................

Goodnight, Charles, quoted.............. 43, 46

Grenfell, W. T., experiments with reindeer.

Griggs, John W., experience with deer...... 42, 46

Harris, R. H., experience with deer.........

Hill, Joshua, experience with elk..........

Hippotragus leucophæus.................

Hornaday, W. T., quoted . . . . . . . . . . . . . .

Hybrids, deer................... 21,23,45 elk.

Hydrelaphus inermis

Illinois, deer from parks.................

Increase of deer in domestication...........

Indiana, deer from parks. ...............

Introduction of foreign animals

Iowa, protection of park deer.

Jackson, Sheldon, introduction of reindeer...

Japanese sika..........................

Kellogg, T. D., tame elk.................

Kentucky, protection of game in parks.....

Killing deer in private parks..............

Land not utilized.

Laws affecting game propagation..........

McKeen, W. R., experience with deer......

Maine, permits to tame game.............

Management of elk

Virginia deer......................

March, C. W., experience in shipping deer...

Massachusetts, killing tame deer...........

Mercer, John, elk in Maryland..............

Michigan, protection of park deer...........

Minnesota, private parks.

Missouri, tame deer.

Moose.

Mule deer.

Muntjacs.

New York, deer from parks

Nilgai.

North Caroling park deer

North Dakota, parks... . . . . . . . . . . . . .

Nowlin, D. C., quoted concerning antelope..

Odocoileus columbianus. . . . . . . . . . . . . . . .

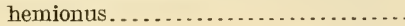

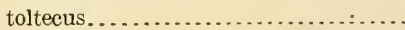

virginianus.

v. couesi.

Oklahoma, deer from parks.

Otzinachson Rod and Gun Club........... 50,55

Parks, private, for deer.................

laws relating to private.............

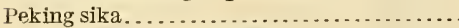

Pennsylvania, private parks............
34,37

56

46

25

24

10

51

51

7,52

3,14

26

46

17

46

43

5

28

24

56

45

56

24

56

17

22

31

56

53

40

52

42

56

36

46

48

56

29

56

56

57

18

20,45

24

57

57

13

57

57

11

21

45

45

0,40

57

50

23

57
Page.

Père David deer. . . . . . . . . . . . . . . . . . . . 23

Powerscourt, Lord, experience with Japanese deer.......................... 22

experience with Sambar deer......... 23

Preservation of species a reason for domesti-

cation.............................. 9

Private deer preserves.................. 55

ownership of deer.................. 55

Protection of antelope.................. 12

Pronghorn ............................. 11

Pseudaxis hortolorum ................... $\quad 23$

nippon.......................... 22

Quagga, extinetion.................... 9

Range of American antelope.............. 11

elk............................. 19

moose........................... 18

mule deer...................... 20

white-tailed deer.................. $\quad 20$

suitable for elk..................... 36

Rangifer areticus........................ 16

caribou.......................... 16

tarandus........................ 16

Reasons for domesticating mammals........ 9

Reindeer, Alaska....................... $\quad 17$

Labrador.......................... 17

Newfoundland................... 17

Roosevelt, Theodore, quoted............ $\quad 39$

Roseberry, C. H., experience with deer..... 44

Russ, Geo. W., on raising elk............ 33

Sale of venison from parks.............. 54

St. Louis Park and Agricultural Company... 33, 45

Sambar, Indian....................... 23

Sika, Japanese......................... 22

Peking......................... 23

South Dakota, private parks............. $\quad 58$

Species suitable for domestication.......... 10

State game preserves.................... 51

laws relating to private ownership of

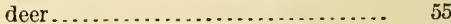

Stratton, E. L., domestication of elk......... 31

Stratton, Lorenzo, domestication of elk..... 29, 36

Taurotragus.......................... 13

Tielenius, Carl, experience with elk........ 28, 33

Transportation of live deer.............. $\quad 52$ venison.......................... 52

use of mammals................... 10

Trapping deer for shipment................ 49

Trouessart, E., domesticating mammals..... 8

Tuley, Joseph, elk in Virginia............. $\quad 29$

Venison, digestibility.................. 14 elk........................... 26

from parks, sale................. 54

Vermont, deer from parks............... 58

Vicious deer.......................... 47

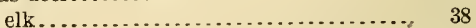

Wapiti................................. 19

Altai............................. 21

North American.................. 19, 25

habits..................... 25

Weber case.......................... 54

Wetmore, M. C., experience with elk ....... 33

Wilson, F. J., experience with elk......... 32

White-tailed deer..................... 20, 40

Whitney, William C.................. 20,28

Wisconsin, private parks................ $\quad 58$

Woburn Abbey, parks of Duke of Bedford. . 13,

$14,22,23$

Worthington, Charles C.......... 47,49,50, 51 





